\title{
Gold and Silver Minerals and Conditions of Their Formation at the Dorozhnoye Deposit (Magadan Region, Russia)
}

\author{
N. E. Savva' ${ }^{1}$, G. A. Palyanova ${ }^{2,3^{*}}$, E. E. Kolova ${ }^{1}$ \\ ${ }^{1}$ North-Eastern Interdisciplinary Science Research Institute, FEB of RAS, Magadan, Russia \\ ${ }^{2}$ Institute of Geology and Mineralogy, SB of RAS, Novosibirsk, Russia \\ ${ }^{3}$ Novosibirsk State University, Novosibirsk, Russia \\ Email: ${ }^{*}$ palyan@igm.nsc.ru
}

Received 24 May 2014; revised 19 June 2014; accepted 3 July 2014

Copyright (C) 2014 by authors and Scientific Research Publishing Inc.

This work is licensed under the Creative Commons Attribution International License (CC BY).

http://creativecommons.org/licenses/by/4.0/

(c) (i) Open Access

\begin{abstract}
This paper presents the brief geological and mineralogical characteristics of the Dorozhnoye mesothermal gold ore deposit (Magadan Region, Russia). The gold and silver minerals are represented by electrum (530\%o - 700\%), freibergite, stephanite, pyrargyrite and Bi-diaphorite. The homogeneous fluid inclusions enable one to determine that the quartz-molybdenite veins were formed at a temperature of $340^{\circ} \mathrm{C}$ to $140^{\circ} \mathrm{C}$, and that the quartz-sulfide gold ore veins were formed at a temperature of $165^{\circ} \mathrm{C}$ to $125^{\circ} \mathrm{C}$. It is assumed that the fluid had a mixed composition and evolved from K-chloride and K-carbonate to Na-chloride. The hypergenesis zone contains: high fineness gold $\left(800 \%\right.$ - 950\%), petrovskaite $(\mathrm{AgAuS})$ and uytenbogaardtite $\left(\mathrm{Ag}_{3} \mathrm{AuS}_{2}\right)$ associated with goethite and melanterite. The surface waters contain: $\mathrm{Ca}^{++}$up to $293 \mathrm{mg} / \mathrm{L}, \mathrm{HCO}_{3}$ up to 125 $\mathrm{mg} / \mathrm{L}, \mathrm{SO}_{4}$ up to $777 \mathrm{mg} / \mathrm{L} ; \mathrm{pH}$ is 5.8 to 7.2 . Thermodynamic calculations have been conducted and Eh-pH diagrams have been built for the $\mathrm{Au}-\mathrm{Ag}-\mathrm{S}-\mathrm{H}_{2} \mathrm{O}$ system at $25^{\circ} \mathrm{C}$ and $100^{\circ} \mathrm{C}(\mathrm{p}=1 \mathrm{bar})$ to reveal gold and silver stability fields. Au-Ag sulfides at the Dorozhnoye deposit are formed under oxidizing conditions and an acidic environment with dominating sulfates.
\end{abstract}

\section{Keywords}

Dorozhnoye Deposit, Au-Ag Minerals, Genesis, Eh-pH Diagrams

\section{Introduction}

The Dorozhnoye gold deposit, located in the granitoids of the Sylgytarsky massif, possesses several specific pe-

*Corresponding author.

How to cite this paper: Savva, N.E., Palyanova, G.A. and Kolova, E.E. (2014) Gold and Silver Minerals and Conditions of Their Formation at the Dorozhnoye Deposit (Magadan Region, Russia). Natural Resources, 5, 478-495.

http://dx.doi.org/10.4236/nr.2014.59044 
culiarities, such as gently dipping $\left(3^{\circ}-5^{\circ}\right)$ veins and low-grade gold found in ores containing silver sulfosalts. This deposit was defined by Firsov [1] as a typical gold-quartz formation. Kalinin [2] in the early part of the 1990s determined the following minerals within the ores: petrovskaite (AgAuS), pyrargyrite $\left(\mathrm{Ag}_{3} \mathrm{AsS}_{3}\right)$, miargyrite $\left(\mathrm{AgSbS}_{2}\right)$, native bismuth, bismuthite $\left(\mathrm{Bi}_{2} \mathrm{~S}_{3}\right)$, and diaphorite $\left(\mathrm{Ag}_{3} \mathrm{~Pb}_{2} \mathrm{Sb}_{3} \mathrm{~S}_{8}\right)$. Pyrargyrite and petrovskaite were also detected and described by Al'shevskii [3]. In 2009, we worked at the Dorozhnoye deposit and detected quartz-molybdenite (Q-Mo) and quartz-cassiterite (Q-Cst) veins accompanying the gold mineralization. We also found stephanite and exceeding Bi concentrations in ores. Our objective was to study the genetic peculiarities that had formed the Au-Ag mineralization, which are not typical of a gold-quartz type occurrence. We studied ore minerals of gold-quartz, quartz-molybdenite and quartz-cassiterite veins and oxidation zones, analyzed the composition of the surface waters, and determined homogenizing temperatures and the composition of fluid inclusions. Furthermore we carried out thermodynamical calculations and built Eh-pH diagrams for the Au-Ag-S- $\mathrm{H}_{2} \mathrm{O}$ system at $25^{\circ} \mathrm{C}$ and $100^{\circ} \mathrm{C}(\mathrm{p}=1 \mathrm{bar}$ ), in order to determine the Au-Ag sulfides stability fields.

\section{General Characteristics of the Dorozhnoye Deposit}

The Dorozhnoye deposit is located in the apical part of the Sylgytarsky ${ }^{1}$ granitoid intrusion. It is situated in the Magadan Region (Russia) near the inhabited locality of Susuman on the right-hand bank of the Dorozhny creek, the left-hand tributary of the Verkhny Neksikan River (Figure 1). The ore field is confined by faults of a north-

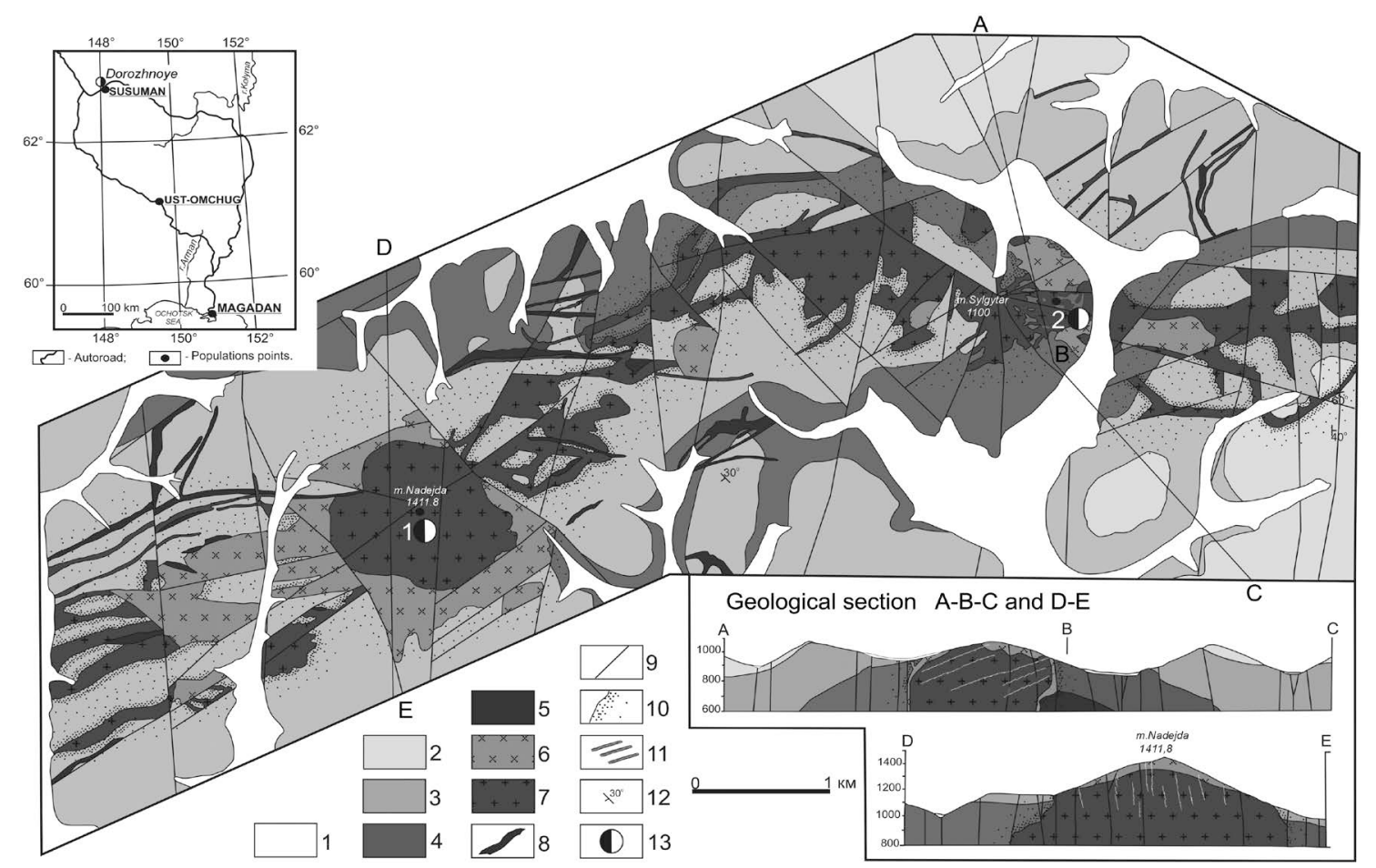

Figure 1. Geological diagram of the Sylgytarsky ore field with alterations [2]; geographical layout of the area is shown in the upper left corner). 1-quaternary system $(\alpha \mathrm{Q})$ - poorly defined formations of alluvium-deluvium sediments: boulders, pebble, gravel, sands, clays; 2 - 5-Jurassic System, lower-medium parts: 2-Zhukovskaya suite $\left(\mathrm{J}_{2} \mathrm{j} \mathrm{k}_{1}\right)$, lower sub-suite, interbedding of sandstones, aleurolites and clay slates; 3 - 4-myaundzhinskaya suite: 3-upper sub-suite $\left(\mathrm{J}_{2} \mathrm{mn}_{2}\right)$, interbedding of sandstones, clay slates, aleurolites, with sparse gravelite lenses; 4 -lower sub-suite $\left(\mathrm{J}_{2} \mathrm{mn}_{3}\right)$, flushoidinterbedding of sandstones, aleurolites, clay slates; 5 -Arensky suite $\left(\mathrm{J}_{1-2} \mathrm{ar}\right)$, thin-bedded aleurolites and aleuro-sandstones with rare interlayers of sericite-siliceous schists; 6 - 7-Early-Cretaceous (Kolymsky) intrusive complex: 6- granodiorites $\left(\gamma \delta \mathrm{K}_{1}\right)$; 7-granodiorite-porphyry $\left(\gamma \delta \pi \mathrm{K}_{1}\right)$; 8-Late-Jurassic-Early-Cretaceous granodiorite dykes $\left(\gamma \delta \mathrm{K}_{1}\right)$, granodioriteporphyry $\left(\gamma \delta \pi \mathrm{K}_{1}\right)$, granite-porphyry $\left(\gamma \pi \mathrm{K}_{1}\right)$, rhyodacites $\left(\pi \varsigma \mathrm{K}_{1}\right)$, dacites $\left(\varsigma \mathrm{K}_{1}\right)$, dioritic porphirites $\left(\delta \pi \mathrm{J}_{3}\right)$; 9 -fractures of I-III orders traced on the surface and detected by ALS scanning, proven by geophysical methods and geochemical field; 10 - contact metamorphism; 11—gold-quartz ore veins and zones of essentially silicified veinlets; 12 - elements of rock occurrence; 13-deposits: 1-Sylgytar; 2-Dorozhnoye.

\footnotetext{
${ }^{1}$ Sylgytar-Sylgy-Ytar, the Yakut for-pasture ground.
} 
westerly strike (the Sredny-Berelyokhsky and the Verkhne-Neksikansky faults) and is part of the Berelyokh ore district confined by the deep Chai-Yurinsky and the Debinsky Faults. The ore field is comprised of the InyaliDebinskymega syncline of the Yano-Kolymskaya folding zone and is composed of terrigenous sand-aleuroliticflyshoid sedimentations of the Verkhoyansk Complex $\left(\mathrm{J}_{1-2}\right)$, compressed into an antyclinal fold of a north-easterly strike and is intersected by numerous faults, possessing a lateral structure.

The outcoming granitoides of the Sylgytarsky pluton $(1.5 \times 9 \mathrm{~km})$ represent an intricately shaped body extended in a sublateral north-easterly direction submerged in the north underneath Triassic sediment formations [4]. According to their composition, these are granodiorites, less frequently granites possessing a content of potassium lime-alkaline and formed in a continental geodynamical environment (Figure 2).

They contain the xenolith of the host rock which belongs to the Lower Jurassic sand-clay sediments. The intrusive body is intersected by a series of tectonic dislocations with small movement. Development operations have been recently commenced in this area. The intrusive body is framed by numerous dykes (andesites, dacites, diorite-porhyrites) of a north-westerly, north-easterly and latitudinal strike located in the fissures of the rupture.

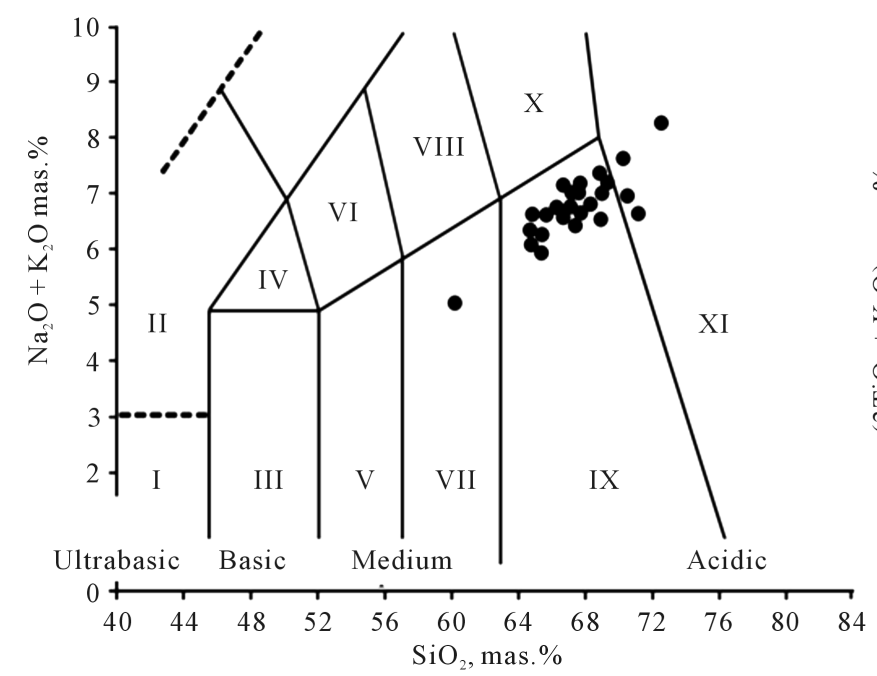

(a)

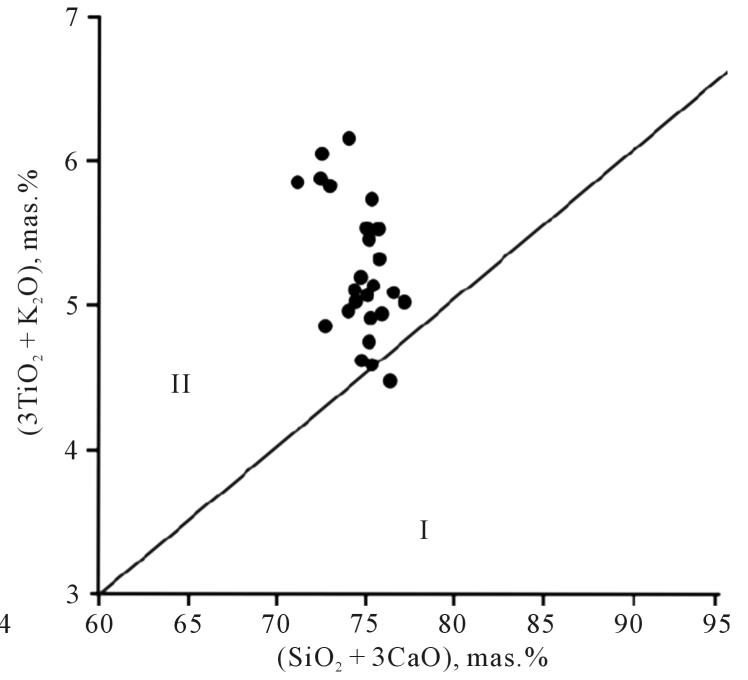

(b)

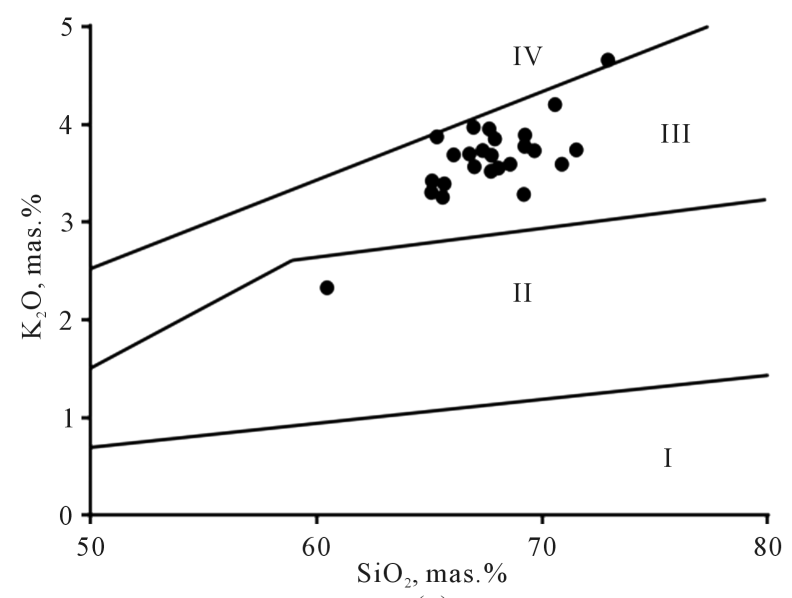

(c)

Figure 2. Classificational characteristics of the Sylgytar stock rocks; based on analytical data by Kalinin [2]. (a) Composition of igneous rock on the diagram $\mathrm{SiO}_{2}-\left(\mathrm{Na}_{2} \mathrm{O}+\mathrm{K}_{2} \mathrm{O}\right)$ [5]: I-picrobasalts (peridotites), II-basanites (foidites), IIIbasalts (gabbro), IV—-trachybasalts (subalkaline gabbro), V-basalt andesite (gabbro-diorite), VI-thrachyandesite (monzodiorite), VII-andesite (diorite), VIII-trachyandesite (monzonite), IX-dacite (granodiorite), X-trachyte, trachydacite (quartz monzonite), XI-rhyolite (granite); (b) Geodynamic environment for the formation of igneous rocks. Fields of diagram [6]: I—island-arc, II—continental; (c) $\mathrm{K}_{2} \mathrm{O}-\mathrm{SiO}_{2}$ ratio in igneous rocks [2]. Fields of diagram [7]: I-low-potassium tholeitic, II-mid-potassium lime-alkali, III-high-potassium lime-alkali, IV—shoshonite. 
As per Firsov [1], intrusions are characterized by multistage formation and the replacement of medium rock by medium-acidic and acidic rocks, thus proving that the magma chamber existed for a significant period of time. The resultant (K-Ar) age periods of plagiogranites date back to the Malm-Lower Cretaceous period (131 - 134 MA). Interrelations between the ore bodies and the intrusive rocks prove that the Dorozhnoye deposit ores were formed during the Early Cretaceous age. The Sylgytarsky stock secondary rock alterations are as follows: sericitization, pelitization and beresitization. In the vicinity of veins, the secondary alterations of plagiogranites are more intensive and are represented by thick greisenization and beresitization zones.

The Dorozhnoye gold-bearing quartz veins (the eastern part of the stock) are $0.1-2.0 \mathrm{~m}$ thick and $800 \mathrm{~m}$ long gently dipping plates, located vertically inside the granitoid stock separated by intervals of $100-120 \mathrm{~m}$. Presumably, these are contraction (concentric) fractures which appeared during a period of granitoid cooling (Figure 3). The veins are of a north-easterly strike and a $10^{\circ}-15^{\circ}$ north-westerly dip. When coming out from granites to hornfels, the veins diverge and then pinch out. The average grade is 8 to $17 \mathrm{~g} / \mathrm{t}$ for Au and 10 to $350 \mathrm{~g} / \mathrm{t}$ for Ag. Some samples are out liers with a gold grade of up to $6 \mathrm{~kg} / \mathrm{t}$. An $800 \mathrm{~g}$ nugget was found. The gold-tosilver ratio is $\mathrm{Au}: \mathrm{Ag} \approx 1: 1-1: 20$. At the Nadezhda occurrence (western part of the stock) the veins are steeply dipping (radial) (Figure 3). The veins form veinlets and veinlet zones. The prevailing thickness of the veinletsis $10-30 \mathrm{~cm}$; the thickness of the ore zones can be up to $2 \mathrm{~m}$. Their strike is sublateral and north-easterly in direction. They dip to the north-west at an angle of $60^{\circ}-80^{\circ}$. The length is up to $125 \mathrm{~m}$. The gold grade is 6 to $25 \mathrm{~g} / \mathrm{t}$, the silver grade is up to $300 \mathrm{~g} / \mathrm{t}$.

Two adits, a mine, several trenches and prospecting holes have been developed at the Dorozhnoye deposit. About 20 vein and vein-veinlet bodies have been explored.

\section{Ore Mineral Composition and Succession of Paragenesis Formation}

In ores the prevailing are filling veins with a massive texture of coarse-grained quartz with strips of flaky mica in the near-selvage vein zones and with sulfide and native gold impregnations. The oxidized zone has a considerable quantity of crusts, sinters, earthy and cellular textures which were generated when sulfides were replaced by hypergene minerals (Figure 4). It is relatively straightforward to distinguish the spatial-temporal interrelations between veins of different composition: the later veins, predominantly carbonate, intersect the earlier quartz veins (gold producing veins). The quartz-molybdenite and quartz-cassiterite veins appeared earlier than the gold-quartz veins and are steeply dipping $\left(70^{\circ}\right)$. The mineralization process can be divided into four stages, based on the study of interrelations between ore veins and veinlets, texture analysis in prospect holes, as well as micromineral intergrowths: the first three stages are classified as "hydrothermal-metasomatic"; the fourth is

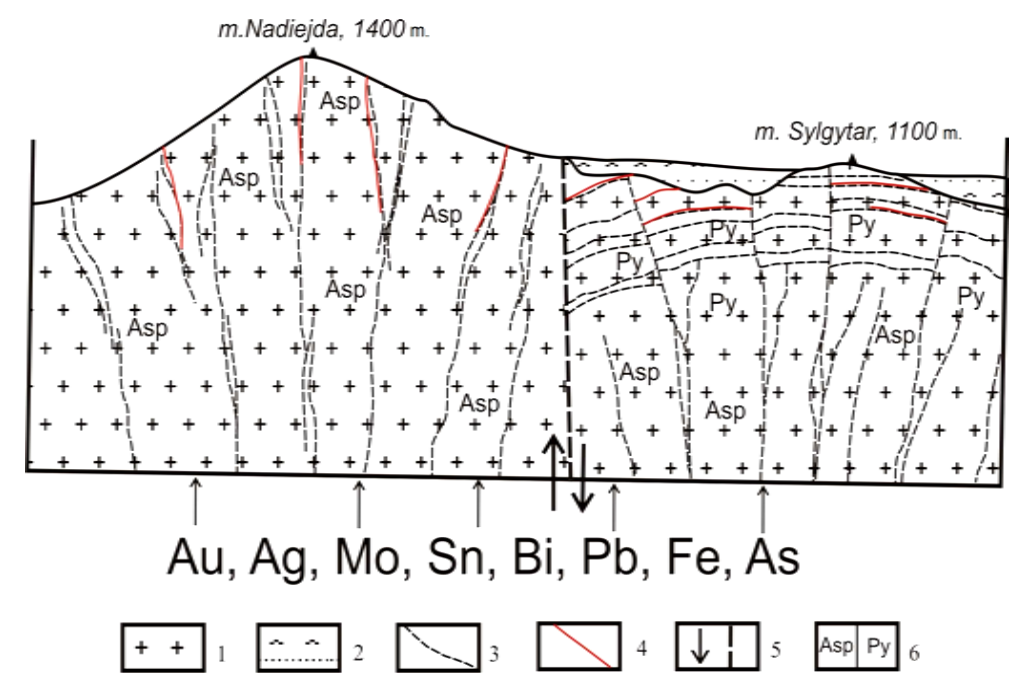

Figure 3. Ore body morphology. a-cross section characterizing various types of mineralized fissures at the Dorozhnoye deposit and the Nadezhda occurrence: 1 -granitoids; 2 -hornfels $\left(\mathrm{J}_{1-2}\right)$; 3 -ore-hosting fissures; 4 gold ore mineralization; 5 -fracture and fault. 


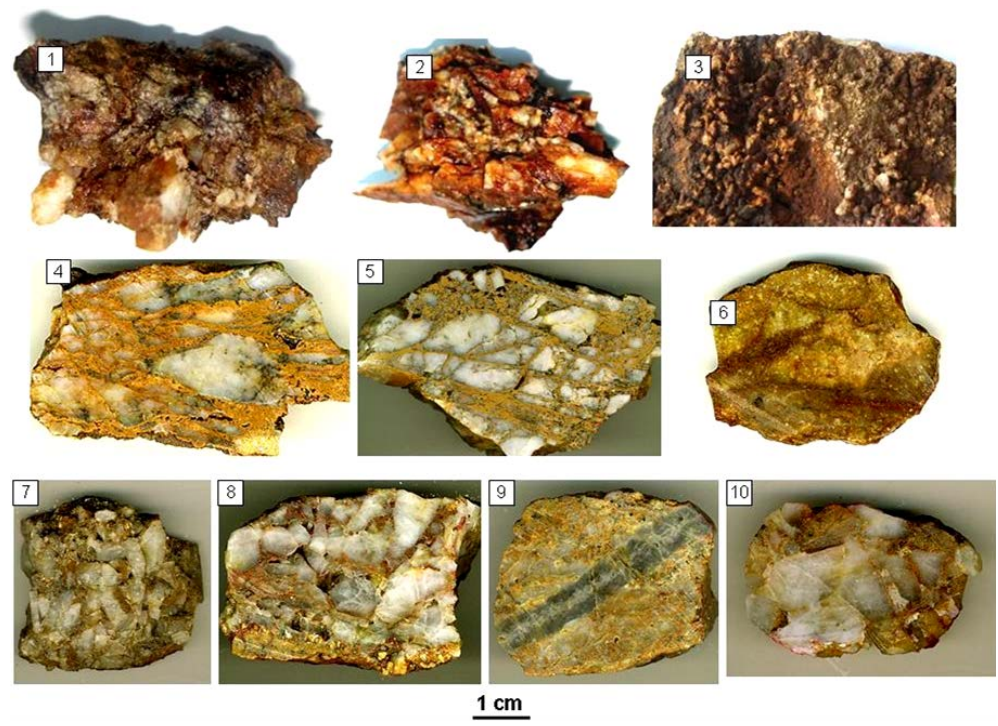

Figure 4. Fe hydroxides in the oxidation zone. 1 - 2-hydro-hematite film on quartz from shatter zone; 3 -Fe hydroxides on the surface of druse-shaped quartz; 4 - 5-melanterite (Fe aqueous sulfate) fills cracks in quartz; 6granite colored by Fe hydroxides; 7 - 8-quartz-muscovite aggregate (muscovite coloured by Fe ocher); 9-quartz-molybdenite veinlet in granite (granite coloured by Fe ocher); 10 - in breccias Fe hydroxides are developed in hornfels debris.

known as "hypergenic" (Table 1). Quartz-molybdenite and quartz-cassiterite parageneses without gold appeared during the first stage. During the second stage, quartz-arsenopyrite stage, galena-electrum-sulfosalts (silver minerals such as freibergite, stephanite, pyrargyrite and Bi-diaphorite) appeared. In the third stage, quartz-carbonate stage does not contain gold and silver mineralization. The fourth "hypergenic" stage occurs in the oxidized zone; it is during this stage that the following appear: high fineness gold, Au-Ag sulfides (petrovskaite, and uytenbogaardtite), together with hydroxides, aqueous sulfates and ferric arsenates.

The succession of ore mineral formation is as follows: hypogenic - quartz + cassiterite $\rightarrow$ quartz + molybdenite + pyrite + pyrrhotite $\rightarrow$ arsenopyrite $\rightarrow$ galena + sphalerite + freibergite + silver minerals $\rightarrow$ electrum $\rightarrow$ hypergenic - high fineness gold (800\% - 950\%), limonite, scorodite, melanterite, petrovskaite, and uytenbogaardtite. Most important are gold and silver minerals in ores (described in more detail below). The chemical composition of these minerals is listed in Table 2.

Native gold is primarily represented by electrum (530\% - 700\%) with rare impregnations of hypergene high fineness gold (800\% - 950\%) (Figure 5).

Gold is most commonly confined to vein selvage and is intergrown with light mica (Figure 6(a)). Furthermore, gold is deposited in interstitia and along cracks in quartz. In addition, gold intergrows with arsenopyrite and galena. Electrum specks have a predominant size of $0.03-3 \mathrm{~mm}$. Nuggets can frequently be found; indeed the largest $800 \mathrm{~g}$ nugget was discovered in a placer deposit. The gold intergrows with coarse-crystalline quartz. According to the atomic absorption analysis, $\mathrm{Hg}(0.1 \mathrm{wt} \%-0.2 \mathrm{wt} \%)$ is present in gold as impurity. Exceeding $\mathrm{Hg}$ content up to $2.35 \mathrm{~g} / \mathrm{t}$ was also found in ore samples.

Freibergite, stephanite, pyrargyrite and Bi-containing diaphorite form 0.01 to $0.1 \mathrm{~mm}$ inclusions (lamellae) in galena, less often-in sphalerite (Figure 7). Freibergite is always intergrown with chalcopyrite (Figure 7 (a)-(c)). 3\% - 5\% of silver minerals are present in galena. Due to the mineral thin inclusions, the silver content in galena monofractions is $8000 \mathrm{~g} / \mathrm{t}$ (atomic-absorbtion analysis, Kalinin 1992). According to microprobe analysis results, freibergite contains Fe up to 5.6 wt\% and Ag up to 25.2 wt\% (Table 2). The Bi concentration in diaphorite is $1.2 \mathrm{wt} \%$.

In contrast to pyrite, arsenopyrite is almost never found in metasomatites but is developed in quartz-sericite veins in the form of clusters consisting of $0.2 \mathrm{~mm}$ to $15 \mathrm{~cm}$ crystalline aggregates. Arsenopyrite consists of bipyramidal and short-prismatic crystals which do not exceed $2 \mathrm{~mm}$ in their longest side. Arsenopyrite intergrows 
Table 1. Succession of hydrothermal mineral formation.

\begin{tabular}{|c|c|c|c|c|}
\hline \multirow{4}{*}{ Minerals } & \multicolumn{4}{|c|}{ Stages } \\
\hline & \multicolumn{3}{|c|}{ Hydrothermal-metasomatic } & \multirow[t]{2}{*}{ Hypergenic } \\
\hline & \multicolumn{3}{|c|}{ Stages } & \\
\hline & Quartz-cassiterite-molybdenite & Quartz-muscovite-arsenopyrite & Quartz-carbonate & Limonite-scorodite \\
\hline \multicolumn{5}{|l|}{ Albite } \\
\hline \multicolumn{5}{|l|}{ Muscovite } \\
\hline \multicolumn{5}{|l|}{ Sericite } \\
\hline \multicolumn{5}{|l|}{ Quartz } \\
\hline \multicolumn{5}{|l|}{ Calcite } \\
\hline \multicolumn{5}{|l|}{ Cassiterite } \\
\hline \multicolumn{5}{|l|}{ Molybdenite } \\
\hline \multicolumn{5}{|l|}{ Pyrrhotite } \\
\hline \multicolumn{5}{|l|}{ Pyrite } \\
\hline \multicolumn{5}{|l|}{ Arsenopyrite } \\
\hline \multicolumn{5}{|l|}{ Galena } \\
\hline \multicolumn{5}{|l|}{ Sphalerite } \\
\hline \multicolumn{5}{|l|}{ Freibergite } \\
\hline \multicolumn{5}{|l|}{ Diaphorite } \\
\hline \multicolumn{5}{|l|}{ Pyrargyrite } \\
\hline \multicolumn{5}{|l|}{ Stephanite } \\
\hline \multicolumn{5}{|l|}{ Electrum } \\
\hline \multicolumn{5}{|l|}{ Limonite } \\
\hline \multicolumn{5}{|l|}{ Scorodite } \\
\hline \multicolumn{5}{|l|}{ Petrovskaite } \\
\hline \multicolumn{5}{|l|}{ Uytenbogaardtite } \\
\hline \multicolumn{5}{|l|}{ High fineness gold } \\
\hline \multicolumn{5}{|l|}{ Melanterite } \\
\hline \multicolumn{5}{|l|}{ Pitticite } \\
\hline Textural features & $\begin{array}{l}\text { Massive (homogeneous quartz } \\
\text { with impregnated molybdenite) }\end{array}$ & $\begin{array}{l}\text { Massive and druse-shaped; } \\
\text { Pocket-impregnated }\end{array}$ & Veinlet & Cellular, earthy \\
\hline $\begin{array}{l}\text { T of homogenization } \\
\text { of fluid inclusions }\end{array}$ & From $360^{\circ} \mathrm{C}$ to $160^{\circ} \mathrm{C}(\mathrm{n}-45)$ & From $165^{\circ} \mathrm{C}$ to $125^{\circ} \mathrm{C}(\mathrm{n}-17)$ & ? & Ambient temperature \\
\hline
\end{tabular}


Table 2. Chemical composition of gold and silver minerals in ores of the Dorozhnoye deposit (wt\%).

\begin{tabular}{|c|c|c|c|c|c|c|c|c|c|c|c|c|}
\hline No & $\mathrm{Cu}$ & $\mathrm{Sb}$ & S & As & $\mathrm{Ag}$ & $\mathrm{Fe}$ & $\mathrm{Zn}$ & $\mathrm{Au}$ & $\mathrm{Pb}$ & $\mathrm{Bi}$ & $\Sigma$ & Mineral formula \\
\hline \multicolumn{13}{|c|}{ Stephanite } \\
\hline $1^{*}$ & 1.57 & 11.18 & 16.82 & 2.56 & 67.62 & - & - & - & - & - & 99.75 & $\begin{array}{c}\left(\mathrm{Ag}_{5.03}, \mathrm{Cu}_{0.19}\right)_{5.22} \\
\left(\mathrm{As}_{0.27}, \mathrm{Sb}_{0.74}\right)_{1.01} \mathrm{~S}_{3.77}\end{array}$ \\
\hline $2^{* *}$ & - & 14.71 & 17.09 & - & 67.89 & - & - & - & - & - & 99.69 & $\mathrm{Ag}_{4.9053} \mathrm{Sb}_{0.942} \mathrm{~S}_{4.153}$ \\
\hline $3^{* *}$ & - & 15.21 & 16.82 & - & 67.79 & - & - & - & - & - & 99.81 & $\mathrm{Ag}_{4.918} \mathrm{Sb}_{0.977} \mathrm{~S}_{4.105}$ \\
\hline $4^{* *}$ & - & 14.59 & 16.90 & - & 66.12 & - & - & - & - & - & 97.61 & $\mathrm{Ag}_{4.865} \mathrm{Sb}_{0.951} \mathrm{~S}_{4.184}$ \\
\hline \multicolumn{13}{|c|}{ Pyrargyrite, freibergite, diaphorite } \\
\hline $5^{* *}$ & - & 22.64 & 17.73 & - & 59.35 & - & - & - & - & - & 99.72 & $\mathrm{Ag}_{2.99} \mathrm{Sb}_{1.01} \mathrm{~S}_{3.0}$ \\
\hline $6^{*}$ & 17.15 & 26.15 & 22.54 & 0.32 & 27.40 & 5.63 & 0.34 & - & - & - & 100.53 & $\begin{array}{c}\left(\mathrm{Ag}_{4.75}, \mathrm{Cu}_{5.04}\right)_{9.79}\left(\mathrm{Fe}_{1.87}, \mathrm{Zn}_{0.10}\right)_{1.97} \\
\left(\mathrm{Sb}_{4.04}, \mathrm{As}_{0.07}\right)_{4.11} \mathrm{~S}_{13.14}\end{array}$ \\
\hline $7^{*}$ & 0.22 & 28.75 & 19.38 & - & 25.20 & - & - & - & 25.25 & 0.85 & 100.15 & $\begin{array}{c}\left(\mathrm{Ag}_{3.1}, \mathrm{Cu}_{0.04}\right)_{3.14}\left(\mathrm{~Pb}_{1.62}, \mathrm{Bi}_{0.05}\right)_{1.67} \\
\mathrm{Sb}_{3.14} \mathrm{~S}_{8.04}\end{array}$ \\
\hline \multicolumn{13}{|c|}{ Petrovskaite } \\
\hline $8^{*}$ & - & - & 8.82 & - & 33.96 & - & - & 56.71 & - & - & 99.49 & $\mathrm{Au}_{0.98} \mathrm{Ag}_{1.07} \mathrm{~S}_{0.94}$ \\
\hline $9^{* *}$ & - & - & 7.77 & - & 33.04 & - & - & 58.23 & - & - & 99.14 & $\mathrm{Au}_{1.05} \mathrm{Ag}_{1.07} \mathrm{~S}_{0.88}$ \\
\hline $10^{* *}$ & - & - & 8.47 & - & 33.10 & - & - & 55.96 & - & - & 97.63 & $\mathrm{Au}_{0.99} \mathrm{Ag}_{1.07} \mathrm{~S}_{0.9}$ \\
\hline $11^{* *}$ & - & - & 8.06 & - & 42.73 & - & - & 49.54 & - & - & 100.32 & $\mathrm{Au}_{0.84} \mathrm{Ag}_{1.32} \mathrm{~S}_{0.83}$ \\
\hline $12^{* *}$ & - & - & 7.76 & - & 43.21 & - & - & 49.15 & - & - & 100.34 & $\mathrm{Au}_{0.83} \mathrm{Ag}_{1.34} \mathrm{~S}_{0.83}$ \\
\hline $13^{* *}$ & - & - & 8.31 & - & 40.59 & - & - & $\begin{array}{c}49.09 \\
(\mathrm{Se}-0.6)\end{array}$ & - & - & 98.60 & $\mathrm{Au}_{0.84} \mathrm{Ag}_{1.27}(\mathrm{~S}, \mathrm{Se})_{0.89}$ \\
\hline $14^{* *}$ & - & - & 7.57 & - & 34.87 & - & - & $\begin{array}{c}56.73 \\
(\text { Se- } 0.6)\end{array}$ & - & - & 99.77 & $\mathrm{Au}_{1.01} \mathrm{Ag}_{1.13}(\mathrm{~S}, \mathrm{Se})_{0.86}$ \\
\hline $15^{* *}$ & - & - & 8.29 & - & 34.51 & - & - & 55.69 & - & - & 98.50 & $\mathrm{Au}_{0.98} \mathrm{Ag}_{1.11} \mathrm{~S}_{0.91}$ \\
\hline $16^{* *}$ & - & - & 7.93 & - & 39.17 & - & - & 54.46 & - & - & 101.57 & $\mathrm{Au}_{0.94} \mathrm{Ag}_{1.23} \mathrm{~S}_{0.83}$ \\
\hline $17^{* *}$ & - & - & 7.78 & - & 42.15 & - & - & 49.68 & - & - & 99.85 & $\mathrm{Au}_{0.85} \mathrm{Ag}_{1.32} \mathrm{~S}_{0.83}$ \\
\hline $18^{* * *}$ & - & - & 11.65 & - & 32.36 & - & - & 51.52 & - & - & 95.54 & $\mathrm{Au}_{0.85} \mathrm{Ag}_{0.97} \mathrm{~S}_{1.18}$ \\
\hline $19^{* * *}$ & - & - & 11.96 & - & 31.94 & - & - & 52.7 & - & - & 96.61 & $\mathrm{Au}_{0.86} \mathrm{Ag}_{0.95} \mathrm{~S}_{1.19}$ \\
\hline \multicolumn{13}{|c|}{ Electrum (Au I) } \\
\hline $20^{* * *}$ & - & - & 0 & - & 41.9 & - & - & 56.45 & - & - & 98.35 & $\mathrm{Ag}_{0.58} \mathrm{Au}_{0.42}$ \\
\hline $21^{* * *}$ & - & - & 0 & - & 42.22 & - & & 54.48 & - & - & 96.7 & $\mathrm{Ag}_{0.59} \mathrm{Au}_{0.41}$ \\
\hline \multicolumn{13}{|c|}{ Uytenbogaardtite } \\
\hline $22^{*}$ & - & - & 10.98 & - & 57.91 & - & - & 30.55 & - & - & 99.44 & $\mathrm{Ag}_{3,12} \mathrm{Au}_{0,9} \mathrm{~S}_{1,98}$ \\
\hline $23^{*}$ & - & - & 10.46 & - & 54.18 & - & - & 35.18 & - & - & 99.82 & $\mathrm{Ag}_{2,99} \mathrm{Au}_{1,06} \mathrm{~S}_{1,94}$ \\
\hline \multicolumn{13}{|c|}{ High fineness gold (Au II) } \\
\hline 25 & - & - & 0 & - & 9.31 & - & - & 91.24 & - & - & 100.56 & \\
\hline 26 & - & - & 0 & - & 8.76 & - & - & 90.86 & - & - & 99.61 & \\
\hline
\end{tabular}

*Analyses were carried out using CAMEBAX EMA (Moscow, TsNIGRI). Analysts: S.M. Sandomirskaya, L.D. Andreeva, M.I. Shavykina. ${ }^{* *}$ Analyses were carried out using CAMEBAX EMA (Magadan, NEISRI FEB RAS). Analysts: E.M. Goryacheva, T.V. Subbotnikova. ${ }^{* * *}$ Analyses were carried out using LEO 1430VP SEM equipped with OXFORD spectrometer (Novosibirsk, IGM SB RAS). Analyst: N.S. Karmanov. Dash— content below sensitivity limit. 


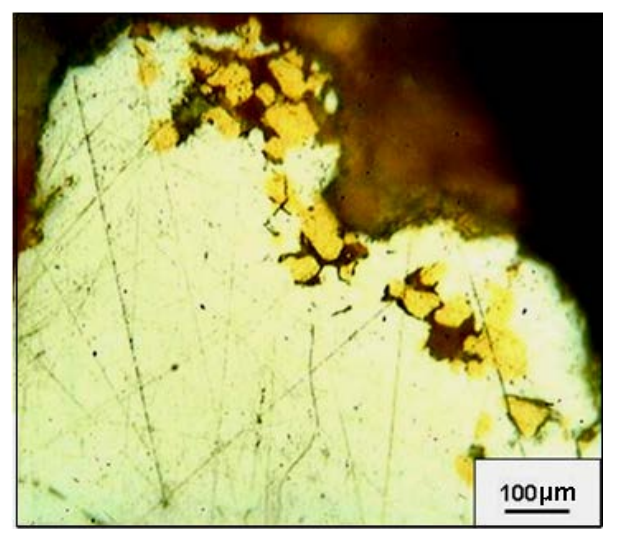

Figure 5. The Dorozhnoye deposit native gold. Gold from two generations: hypogenic electrum (light) and hypergenic high fineness gold (dark).
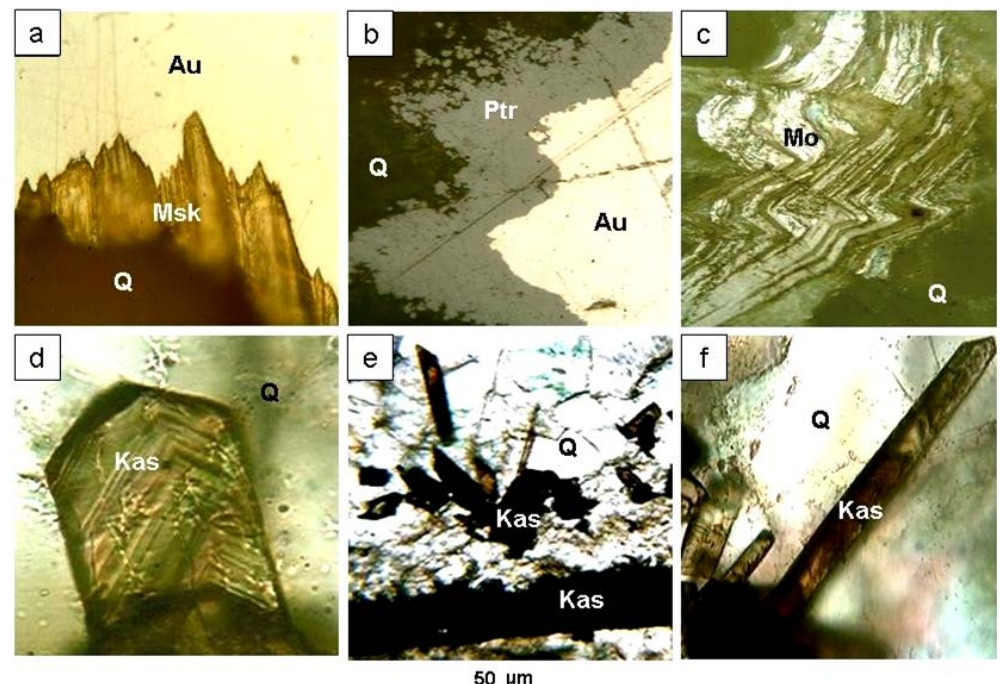

Figure 6. Intergrowths of ore minerals: (a) Native gold (Au) with muscovite (Msc) in quartz (Q); (b) Petrovskaite rim (Ptr) on native gold (Au); (c) Molybdenite (Mo) in quartz (Q); (d)-(f) Intergrowth of cassiterite (Kas) with quartz (Q).

with galena and electrum.

Galena is encountered in the form of $1-25 \mathrm{~mm}$ xenomorphic nests in the quartz filling vein. Galena contains various silver mineral lamellae (pyrargyrite, stephanite, diaphorite) (Figure 7(a)-(e)) and inter grows with electrum.

Pyrite is presented in the form of impregnations in metasomatites and is rarely encountered in veins. Pyrite is usually idiomorphic-granular and makes up a $1 \mathrm{~mm}$ sized cubic habit. Occasionally it is possible to find flameshaped pyrite formations replacing pyrrhotite.

Sphalerite-black-marmatite with emulsion chalcopyrite impregnations; in a similar fashion to galena, sphalerite forms xenomorphic segregations of up to $1.5 \mathrm{~mm}$, and contains small freibergite inclusions (Figure 7(d), Figure 7(e), Figure 7(f)).

Molybdenite - was found in a $20 \mathrm{~cm}$ thick violet-gray semi-transparent quartz vein. Flakes which are smaller than $5 \mathrm{~mm}$ are often curved (Figure 7(c)).

Cassiterite-was found in $5-7 \mathrm{~cm}$ thick symmetric-columnar quartz veins. Cassiterite occurs in selvages taking the form of long-prismatic idiomorphic crystal habit with zonal colouring (Figure 6(c), Figure 6(d)). 

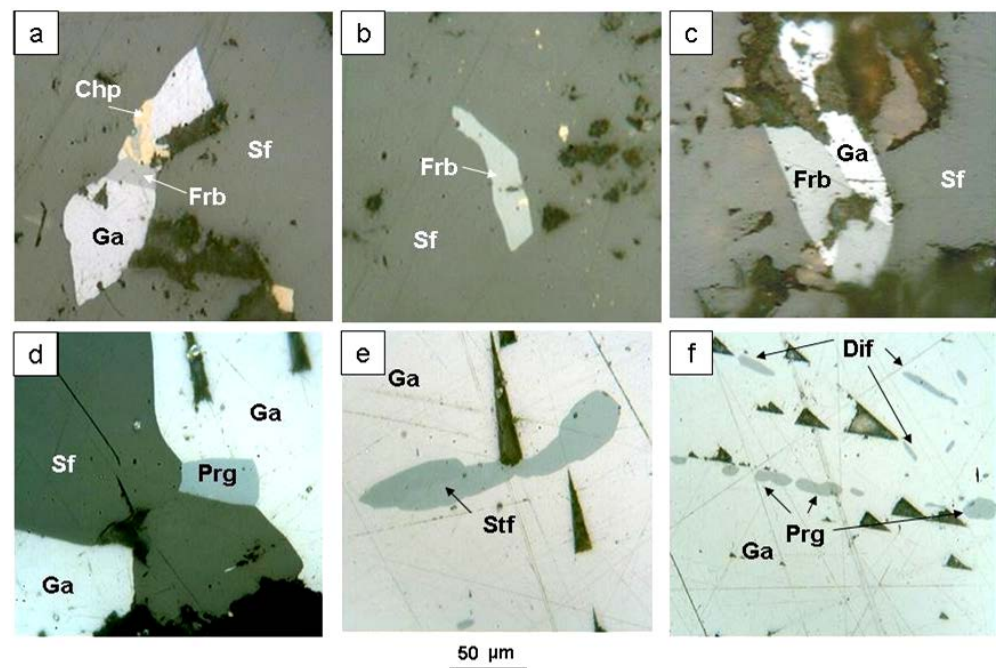

Figure 7. I Intergrowths of silver minerals with galena and sphalerite. (a) Galenainclusion $(\mathrm{Ga})$ in sphalerite $(\mathrm{Sf})$, galena intergrows with freibergite (Frb) and chalcopyrite (Ccp); (b) Freibergite inclusion (Frb) in sphalerite (Sf), fine light fines in sphalerite-chalcopyrite; (c) Intergrowth of freibergitea (Fbr) with galena (Ga) in sphalerite (Sf); (d) Intergrowth of sphalerite (Sf), galena (Ga) and pyrargyrite (Prg); (e) Stephanite inclusion (Stf) in galena (Ga); (f) Pyrargyrite lamellae (Prg) and diaphorite lamellae (Dif) in galena (Ga).

Prismatic crystals grow, like quartz, from selvages towards the center. Cassiterite crystals in the hanging wall are significantly longer (up to $5 \mathrm{~mm}$ ), and in the foot wall they do not exceed $1.5 \mathrm{~mm}$.

The zone of oxidation at the Dorozhnoye deposit is intensively developed, which is confirmed by electric prospecting [4]. Amongst the hypergene minerals we have detected high fineness gold (900\%o - 950\%), petrovskaite, occasionally uytenbogaardtite, which creates up to $0.1 \mathrm{~mm}$ thick films and rims on native gold of fineness $600 \%$ - 680\%. Furthermore we have detected iron hydroxide-goethite and limonite, as well as aqueous iron sulfate (melanterite, $\mathrm{FeSO}_{4} \cdot 7 \mathrm{H}_{2} \mathrm{O}$ ), a considerable amount of scorodite, and a small amount of pitticite.

Petrovskaite (AuAgS) and uytenbogaardtite $\left(\mathrm{Ag}_{3} \mathrm{AuS}_{2}\right)$. About $70 \%$ of gold specs encountered on the surface, are covered with a dark rims which is up to $0.3 \mathrm{~mm}$ thick (Figure 8(a), Figure 8(b)). It occurs rather frequently that the flake-shaped petrovskaite aggregate near these crusts penetrates into the cellular limonite aggregate at a depth of $1 \mathrm{~mm}$. The X-ray studies showed that the Au-Ag sulfides are identical in characteristics to uytenbogaardtite or petrovskaite (sheets No. 20-461 or 33-0587, 19-1146, JCPDS 1999). In order to determine the variations of concentrations the micro-X-ray spectral analysis was implemented: 7.76 - 11.96 for sulfur, 31.94 - 43.21 for silver, $49.09 \mathrm{wt} \%$ - $58.32 \mathrm{wt} \%$ for gold. Petrovskaite contains selenium impurity up to $0.6 \mathrm{wt} \%$ (Table 2).

Uytenbogaardtite and petrovskaite at the Dorozhnoye deposit have a hypergene genesis, like at the Ulakhan and the Krutoye deposits [8]-[10].

\section{Analysis of Fluid Inclusions in Quartz}

Quartz is the primary vein mineral of the Dorozhnoye deposit. Since quartz is prevailing, the ore formation is referred to as a gold-quartz formation. Quartz contains a significant amount of genetic in formation hence it is described in more detail. The vein-filling, gold-bearing white semi-transparent quartz has a medium- and coarsegrain structure. When the veins are thicker, the quartz structure becomes drusy. In selvages quartz intergrows with sericite and has pockets and impregnations of ore minerals. The crystals are upto $2.5 \mathrm{~cm}$ long. Quartz has numerous cataclasis cracks and is intersected by thin quartz-chalcedonic-type veinlets with a large amount of calcite and ankerite pockets. Quartz from veinlets with molybdenite has a violet-grey tint and a cryptocrystalline texture. Quartz was studied using the derivatography method. Micro-impurities were detected using spectral analysis. Thermobarogeochemical studies of the fluid inclusions (FI) have been conducted.

Quartz transition temperatures $\alpha-\beta$ were studied using the method of derivatography on a TERMOSCAN 


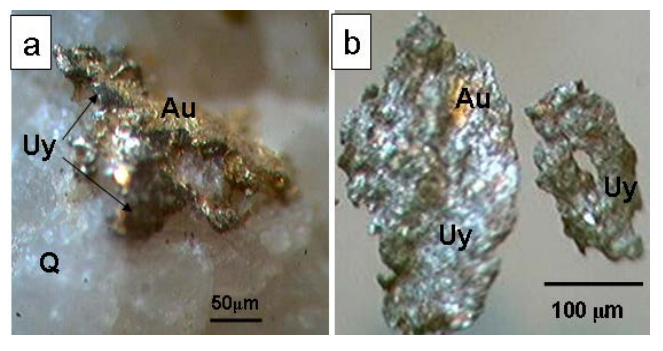

Figure 8. Uytenbogaardtite (Uy) films on native gold (a), (b).

scanner. $\mathrm{T}_{\alpha-\beta}$, established for quartz from gold-bearing and molybdenite veins differ: the former are $554.0^{\circ} \mathrm{C}$ and $555.8^{\circ} \mathrm{C}$, whilst the latter are $558.8^{\circ} \mathrm{C}$ and $559.9^{\circ} \mathrm{C}$. The quartz transition $\alpha-\beta$ temperatures of gold-bearing veins correspond to shallow deposits [11] and to $\mathrm{T}_{\alpha-\beta}$ quartz polychromous volcanogenic-plutogenic gold-silver deposits. For quartz from molybdenite and quartz-cassiterite veins $\mathrm{T}_{\alpha-\beta}-560^{\circ} \mathrm{C}$ is close to gold-telluride-bismuth ore manifestation

A spectral analysis of micro-impurities in quartz showed that the maximum concentrations for gold-bearing quartz are as follows: $\mathrm{Bi}-1.33 \mathrm{~g} / \mathrm{t}$; $\mathrm{Sn}-4.86$; $\mathrm{Pb}-223.31 ; \mathrm{Zn}-69.39$; $\mathrm{Sb}-56.89 \mathrm{~g} / \mathrm{t}$, which characterizes a predominantly volcanogenic (low-temperature) type of mineralization. At the same time, the amounts of $\mathrm{Bi}$ $(12.1 \mathrm{~g} / \mathrm{t})$ and $\mathrm{Sn}(8.9 \mathrm{~g} / \mathrm{t})$ in quartz taken from a quartz-molybdenite vein, are closer to the plutonogenic ore formation [12]. According to the received data, the spatial location of quartz-muscovite gold-bearing veins shows that they are close to shallow deposits (formation of a granite pluton in the apical part, underneath the hornfels screen, on the periphery of the magma chamber).

Quartz FI studies were carried out at the Ore Genesis Lab, NEISRI FEB RAS, using a measuring complex with LinkamTHMSG-600 microthermo camera, a Motic microscope equipped with an Olympus $\times 50$ long-focus objective, and a Moticam solution 3 px. video camera. The homogenization temperature $\left(T_{\text {hom. }}\right.$ ) of two-phase inclusions was determined by the gas-solution transition point. No pressure allowance was entered, so the $T_{\text {hom. }}$ is compliant with the minimum temperature of the mineral formation. The composition and concentration of solutions were studied using the cryometric method. The salt composition of solutions was determined by eutectic melting points $\left(\mathrm{T}_{\text {eut. }}\right)[13]$ and their concentration in $\mathrm{wt} \%$ eq. $\mathrm{NaCl}$ was determined by the melting point of ice ( $\left.\mathrm{T}_{\text {melt. }}\right)$ [14]. The FI was related to genetic types in compliance with the established criteria [15]-[17].

Thermometric studies were conducted for samples from quartz-sulfide, quartz-molybdenite and quartz-cassiterite veins. Fluid inclusions in them were predominantly primary-secondary and secondary, the latter being grouped in flat traces along cracks. 4 - $15 \mu \mathrm{m}$ primary-secondary ones were taken for the study. This type is made up of singular isometric-shaped inclusions. The prevailing were the fluid inclusions containing a gas bulb and water solution with an absence of minute satellite crystals.

A wide range of homogenization temperatures $\left(\mathrm{T}_{\text {hom. }}\right)$ was established for fluid inclusions within quartz-molybdenite material, i.e. from $340^{\circ} \mathrm{C}$ to $140^{\circ} \mathrm{C}$ (n-45), while inclusions of gold-quartz-sulfide material are characterized by a narrow range of $165^{\circ} \mathrm{C}$ to $125^{\circ} \mathrm{C}(\mathrm{n}-17)$. The salinity of quartz fluid inclusions during the quartz-molybdenite stage is high: from $6.5 \mathrm{wt} \%$ to $11.7 \mathrm{wt} \%$ eq. $\mathrm{NaCl}(\mathrm{n}-13)$, and in the quartz-sulfide stage it is low: from $0.18 \mathrm{wt} \%$ to $4.95 \mathrm{wt} \%$ eq. $\mathrm{NaCl}$ (n-11) (Figure 9). Fluid inclusions with lower concentrations of salt (below 6 wt $\%$ eq. $\mathrm{NaCl}$ ) have eutectic points $\left(\mathrm{T}_{\text {eut. }}\right.$ ) ranging from $-15^{\circ} \mathrm{C}$ to $-27.6^{\circ} \mathrm{C}$, which proves the $\mathrm{Na}-(\mathrm{Mg})$-chloride composition of fluids. Fluid inclusions with higher salt concentrations ( $7 \mathrm{wt} \%$ to $11.7 \mathrm{wt} \%$ eq. $\mathrm{NaCl}$ ) have eutectic points $\left(\mathrm{T}_{\text {eut }}\right)$ of $-12^{\circ} \mathrm{C}--17^{\circ} \mathrm{C}$ and $-21.7^{\circ} \mathrm{C}--23^{\circ} \mathrm{C}$, which entails that the fluid is of a mixed composition (differentiation is possible) from K-chloride and K-carbonate to Na-chloride (Table 3).

The water chemistry in water streams of the Dorozhny creek basin (Magadan Region) is as follows: $\mathrm{SO}_{4}$ from 57.6 to $777 \mathrm{mg} / \mathrm{L}, \mathrm{HCO}_{3}$ from 14 to $125 \mathrm{mg} / \mathrm{L}, \mathrm{Ca}^{++}$from 21 to $293 \mathrm{mg} / \mathrm{L}$ (Table 4), little amounts of Na and K, i.e. mainly calcium-sulfate-carbonate water. Chloride concentrations are low because $\mathrm{Cl}<0.01 \mathrm{mg} / \mathrm{L}$. $\mathrm{pH}$ of solutions varies within the range 5.8 - 7.2.

\section{Eh-pH Diagrams of the Au-Ag-S- $\mathrm{H}_{2} \mathrm{O}$ System}

Eh-pH diagrams and $\log \mathrm{f}_{2}-\mathrm{pH}$ for the Au-Ag-S- $\mathrm{H}_{2} \mathrm{O}$ system were built in the works [18]-[21]. They display 

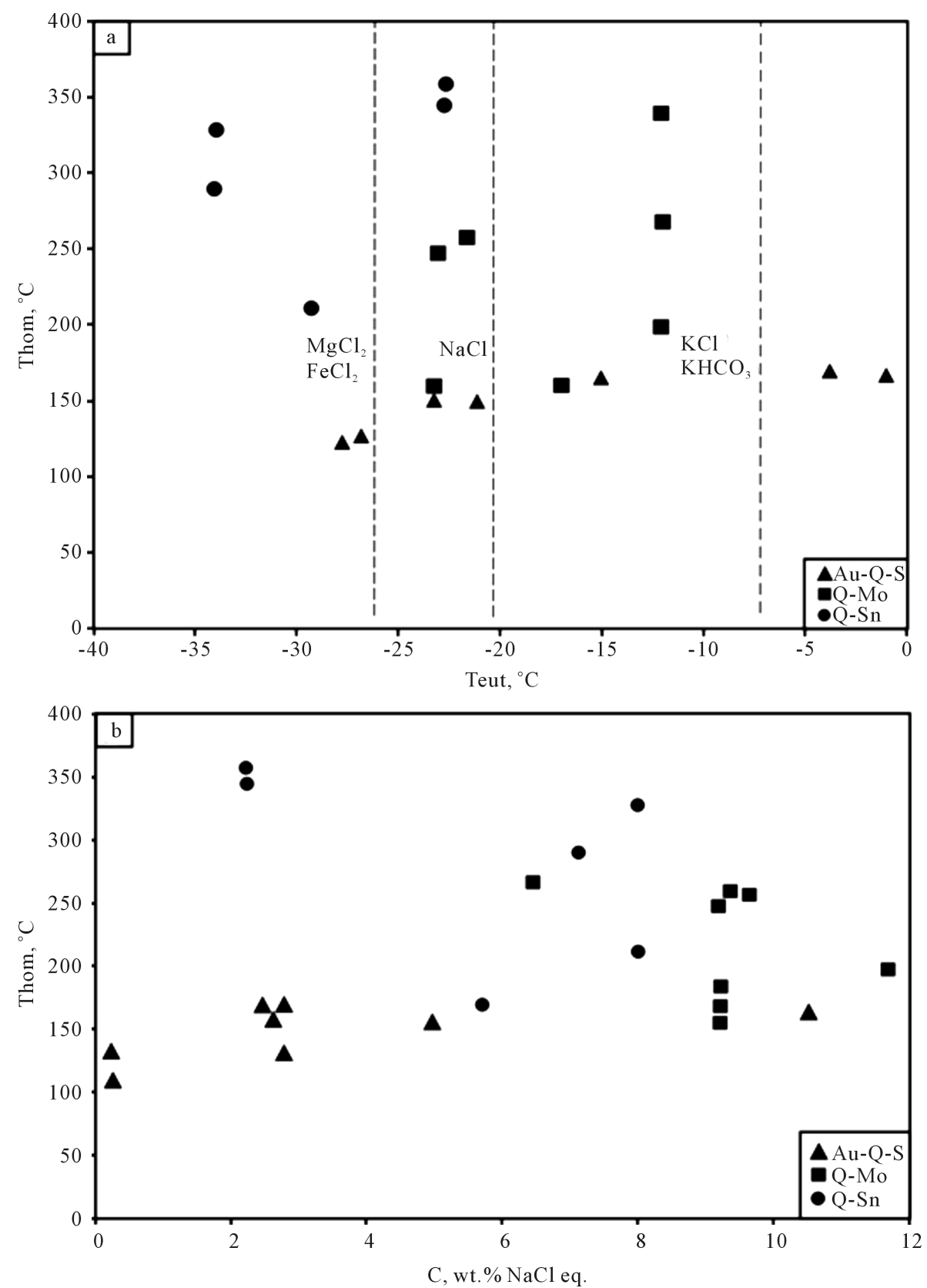

Figure 9. Diagrams of ratios: (a) homogenization temperature-eutectic temperature and (b) homogenization temperature-concentration (salinity) in fluid inclusions from quartz of gold-quartz-sulfide (Au-Q-S), quartz-molybdenite (Q-Mo) and quartz-cassiterite (Q-Cst) mineral associations of the Sylgytarsky ore field.

the native gold stability field of differing fineness in the crusts of weathering; however, these works do not consider the possibility of the formation of uytenbogaardtite and petrovskaite. In order to eliminate this omission and to determine the gold and silver sulfides stability fields, Eh-pH diagrams were constructed. In order to simplify the calculations, we dealt only with the basic dissolved sulfur species-sulfides $\left(\mathrm{H}_{2} \mathrm{~S}, \mathrm{HS}^{-}\right.$and $\left.\mathrm{S}^{2-}\right)$ and sulfates $\left(\mathrm{HSO}_{4}^{-}\right.$and $\mathrm{SO}_{4}^{2-}$ ). According to model calculations made in the works of Krupp and Weiser [18], Savva and Palyanova [9], thiosulfates and other dissolved sulfuric forms are indeed present in small amounts.

Source thermodynamic data. Review of Gibbs standard free energies $\left(\Delta_{\mathrm{f}} \mathrm{G}_{25^{\circ} \mathrm{C}, 1 \mathrm{bar}}\right)$ of $\mathrm{Au}-\mathrm{Ag}$ sulfides has been provided [9]. For uytenbogaardtite the difference in $\Delta_{\mathrm{f}} \mathrm{G}_{25^{\circ} \mathrm{C} \text {, 1bar }}^{\circ}$ between the extreme values is 10.7 
Table 3. Results of thermo- and cryometric studies of individual fluid inclusions within quartz in veins and veinlets of the Sylgytarsky ore field.

\begin{tabular}{|c|c|c|c|c|c|c|c|c|}
\hline \multirow{2}{*}{$\begin{array}{l}\text { Mineral } \\
\text { association }\end{array}$} & \multirow{2}{*}{$\begin{array}{l}\text { Type of fluid } \\
\text { inclusion }\end{array}$} & \multicolumn{6}{|c|}{ Temperatures of phase transitions, ${ }^{\circ} \mathrm{C}$} & \multirow{2}{*}{$\begin{array}{c}\text { Estimated } \\
\text { C salts, wt\%-eq. } \mathrm{NaCl}\end{array}$} \\
\hline & & $\mathrm{T}_{\text {eut. }}$ & $T_{\text {ice melt. }}$ & T gas-hydrate & $\mathrm{T}_{\mathrm{CO}_{2} \text { melt. }}$ & $\mathrm{T}_{\text {hom..CO }}$ & $\mathrm{T}_{\text {hom.(liquid-gas) }}$ & \\
\hline Q-Ars-Mo & $\mathrm{L}$ & -12 & -4 & $\mathrm{~N}$ & $\mathrm{~N}$ & $\mathrm{~N}$ & $339.5-268$ & 6.45 \\
\hline Q-Ars-Mo & $\mathrm{L}$ & -22 & -6.3 & $\mathrm{~N}$ & $\mathrm{~N}$ & $\mathrm{~N}$ & $258-247$ & 9.6 \\
\hline Q-Ars-Mo & $\mathrm{L}$ & -12 & -7 & $\mathrm{~N}$ & $\mathrm{~N}$ & $\mathrm{~N}$ & $198-165$ & 10.49 \\
\hline Au-Q-S & $\mathrm{L}$ & -3 & -1.6 & $\mathrm{~N}$ & $\mathrm{~N}$ & $\mathrm{~N}$ & $162-159$ & 2.74 \\
\hline Au-Q-S & $\mathrm{L}$ & -23 & -3 & $\mathrm{~N}$ & $\mathrm{~N}$ & $\mathrm{~N}$ & $154-150$ & 4.96 \\
\hline Au-Q-S & $\mathrm{L}$ & -27.3 & $\mathrm{~N}$ & $\mathrm{~N}$ & $\mathrm{~N}$ & $\mathrm{~N}$ & $139-126$ & $\mathrm{~N}$ \\
\hline Q-Cst & $\mathrm{L}$ & -22.7 & -1.3 & $\mathrm{~N}$ & $\mathrm{~N}$ & $\mathrm{~N}$ & $358-347$ & 2.24 \\
\hline Q-Cst & $\mathrm{L}$ & -29.3 & -5.1 & $\mathrm{~N}$ & $\mathrm{~N}$ & $\mathrm{~N}$ & $330-212$ & 8.0 \\
\hline Q-Cst & $\mathrm{L}$ & $\mathrm{N}$ & -3.6 & $\mathrm{~N}$ & $\mathrm{~N}$ & $\mathrm{~N}$ & 170 & 5.71 \\
\hline Q-Cst & $\mathrm{LC}^{*}$ & -34 & -7.8 & 11.1 & -60.1 & 8.5 (Liq.) & 328 & 8 \\
\hline Q-Cst & $\mathrm{LC}^{*}$ & -34 & -7 & 11.1 & -59.8 & -0.2 (Liq.) & 290 & 7.1 \\
\hline Q-Cst & $\mathrm{C}^{*}$ & $\mathrm{~N}$ & $\mathrm{~N}$ & $\mathrm{~N}$ & -60.4 & 8.8 (Liq.) & $\mathrm{N}$ & $\mathrm{N}$ \\
\hline Q-Cst & $\mathrm{C}$ & $\mathrm{N}$ & $\mathrm{N}$ & $\mathrm{N}$ & -60.3 & 6.4 (Liq.) & $\mathrm{N}$ & $\mathrm{N}$ \\
\hline Q-Cst & $\mathrm{C}$ & $\mathrm{N}$ & $\mathrm{N}$ & $\mathrm{N}$ & -60.4 & 4.7 (Liq.) & $\mathrm{N}$ & $\mathrm{N}$ \\
\hline Q-Cst & $\mathrm{C}$ & $\mathrm{N}$ & $\mathrm{N}$ & $\mathrm{N}$ & -49.2 & $-26.6(\mathrm{G})$ & $\mathrm{N}$ & $\mathrm{N}$ \\
\hline
\end{tabular}

Each line describes a group of inclusions (not less than 5) with PTX parameters detected in one or several standard samples; N-No phase transition or indistinct; LC—carbon dioxide liquid, C—gas, L-two-phase gas-liquid; Liq.-homogenization of carbon dioxide gas in liquid phase; G—into gas phase; *data obtained jointly with Doctor of Geology and Mineralogy V.Y. Prokof'ev at the A.G. Betekhtin Laboratory of Ore Deposits , IGEM RAS (Institute of Geology of Ore Deposits, Petrography, Mineralogy, and Geochemistry, RAS).

Table 4. Dorozhny basin water chemistry (Magadan Region).

\begin{tabular}{|c|c|c|c|c|c|c|c|c|c|c|c|c|c|c|c|}
\hline \multirow{2}{*}{$\begin{array}{c}\text { Sample } \\
\text { No. }\end{array}$} & \multirow{2}{*}{$\begin{array}{l}\text { Measurement } \\
\text { units }\end{array}$} & \multicolumn{7}{|c|}{ Cations } & \multicolumn{6}{|c|}{ Anions } & \multirow{2}{*}{$\begin{array}{c}\text { Total } \\
\text { mineralization }\end{array}$} \\
\hline & & $\mathrm{Na}^{+}$ & $\mathrm{K}^{+}$ & $\mathrm{Ca}^{++}$ & $\mathrm{Mg}^{++}$ & $\mathrm{NH}_{4}^{+}$ & $\begin{array}{c}\mathrm{Fe} \\
\text { total }\end{array}$ & $\begin{array}{l}\text { Cations } \\
\text { total }\end{array}$ & $\mathrm{HCO}_{3}$ & $\mathrm{SO}_{4}$ & $\mathrm{Cl}$ & $\mathrm{NO}_{2}$ & $\mathrm{NO}_{3}$ & $\begin{array}{c}\text { Anions } \\
\text { total }\end{array}$ & \\
\hline \multirow{3}{*}{1} & $\mathrm{mg} / \mathrm{L}$ & 9.20 & 1.07 & 293.0 & 23.40 & 0.20 & 0.3 & 327.17 & 21.35 & 777.12 & 0.0 & 0.0 & 1.4 & 799.87 & 1127.04 \\
\hline & mg-equiv./L $\quad 6.2^{*}$ & 0.40 & 0.03 & 14.65 & 1.92 & 0.011 & 0016 & 17.03 & 0.35 & 16.19 & 0.0 & 0.0 & 0.02 & 16.56 & 33.59 \\
\hline & \%mg-equiv./L (6.6) & 2.35 & 0.18 & 86.04 & 11.28 & 0.06 & 0.09 & 100 & 2.11 & 97.76 & 0.0 & 0.0 & 0.13 & 100 & \\
\hline \multirow[t]{2}{*}{2} & mg-equiv./L $\quad 7.1^{*}$ & 0.08 & 0.01 & 12.69 & 0.87 & 0.0 & 0.005 & 13.59 & 0.65 & 12.28 & 0.0 & 0.0 & 0.03 & 12.96 & 26.55 \\
\hline & \%mg-equiv./L (7.2) & 0.59 & 0.07 & 92.90 & 6.40 & 0.0 & 0.04 & 100 & 5.02 & 94.75 & 0.0 & 0.0 & 0.23 & 100 & \\
\hline \multirow{3}{*}{3} & $\mathrm{mg} / \mathrm{L}$ & 7.34 & 0.69 & 93.60 & 25.80 & 0.35 & 0.2 & 127.98 & 123.22 & 257.76 & 0.0 & 0.0 & 1.1 & 382.08 & 510.06 \\
\hline & mg-equiv./L $\quad 7.2^{*}$ & 0.32 & 0.02 & 4.68 & 2.12 & 0.019 & 0.011 & 7.17 & 2.02 & 5.37 & 0.0 & 0.0 & 0.02 & 7.41 & 14.58 \\
\hline & \%mg-equiv./L (7.2) & 44.46 & 0.28 & 65.27 & 29.57 & 0.27 & 0.15 & 100 & 27.26 & 72.47 & 0.0 & 0.0 & 0.27 & 100 & \\
\hline \multirow[b]{2}{*}{4} & $\mathrm{mg} / \mathrm{L}$ & 0.93 & 0.09 & 21.40 & 2.07 & 0.30 & 0.4 & 25.19 & 14.03 & 57.60 & 0.0 & 0.0 & 0.60 & 72.23 & 97.42 \\
\hline & mg-equiv./L $\quad 5.8^{*}$ & 0.04 & 0.002 & 1.07 & 0.17 & 0.017 & 0.021 & 1.32 & 0.23 & 1.20 & 0.0 & 0.0 & 0.01 & 1.44 & 2.76 \\
\hline \multirow{3}{*}{5} & $\mathrm{mg} / \mathrm{L}$ & 3.2 & 0.52 & 32.20 & 3.80 & 0.20 & 0.3 & 40.22 & 32.33 & 64.80 & 0.0 & 0.0 & 2.3 & 99.43 & 139.65 \\
\hline & mg-equiv./L $\quad 6.4^{*}$ & 0.09 & 0.013 & 1.61 & 0.31 & 0.011 & 0.016 & 2.05 & 0.53 & 1.35 & 0.0 & 0.0 & 0.04 & 1.92 & 3.97 \\
\hline & \%mg-equiv./L (6.6) & 4.39 & 0.63 & 78.54 & 15.12 & 0.54 & 0.78 & 100 & 27.61 & 70.31 & 0.0 & 0.0 & 2.08 & 100 & \\
\hline \multirow{3}{*}{6} & $\mathrm{mg} / \mathrm{L}$ & 3.81 & 0.64 & 51.0 & 12.90 & 0.40 & 0.5 & 69.25 & 73.20 & 112.80 & 0.0 & 0.0 & 2.2 & 188.2 & 257.45 \\
\hline & mg-equiv./L $\quad 7.1^{*}$ & 0.17 & 0.028 & 2.55 & 1.06 & 0.022 & 0.027 & 3.86 & 1.20 & 2.35 & 0.0 & 0.0 & 0.04 & 3.59 & 7.45 \\
\hline & \%mg-equiv./L (7.2) & 4.41 & 0.73 & 66.11 & 27.48 & 0.57 & 0.70 & 100 & 33.4 & 65.46 & 0.0 & 0.0 & 1.11 & 100 & \\
\hline \multirow{3}{*}{7} & $\mathrm{mg} / \mathrm{L}$ & 8.06 & 0.67 & 123.6 & 33.90 & 0.15 & 0.5 & 166.88 & 125.66 & 338.4 & 0.0 & 0.0 & 2.40 & 466.46 & 633.34 \\
\hline & mg-equiv./L $\quad 7.2^{*}$ & 0.35 & 0.017 & 6.18 & 2.79 & 0.008 & 0.027 & 9.37 & 2.06 & 7.05 & 0.0 & 0.0 & 0.04 & 9.15 & 18.52 \\
\hline & \%mg-equiv./L (7.2) ${ }^{* *}$ & 3.74 & 0.18 & 65.94 & 29.77 & 0.08 & 0.28 & 100 & 22.51 & 77.05 & 0.0 & 0.0 & 0.44 & 100 & \\
\hline
\end{tabular}

*Laboratory test result; ${ }^{* *}$ Field test result; NEISRI FEB RAS, analyzed by: D.S. Krotova NEISRI FEB RAS. 
$\mathrm{kJ} / \mathrm{mol}$, for petrovskaite it is $6.4 \mathrm{~kJ} / \mathrm{mol}$, and for acantite $\mathrm{Ag}_{2} \mathrm{~S}$ it is 1.13 . The calculations used $\mathrm{G}_{25^{\circ} \mathrm{C}, 1 \text { bar }}$ $\mathrm{Ag}_{3} \mathrm{AuS}_{2}$ and AgAuS [22], intermittent data. Source thermodynamical data for argentite, acanthite $\left(\alpha, \beta-\mathrm{Ag}_{2} \mathrm{~S}\right)$, chlorargyrite $(\mathrm{AgCl})$, halite $(\mathrm{NaCl})$, sulfur $(\mathrm{S})$, gold $(\mathrm{Au})$ and silver $(\mathrm{Ag})$ were taken from [23], for $\mathrm{Ag}_{2} \mathrm{SO}_{4}$, $\mathrm{Ag}_{2} \mathrm{O}$ from [18].

Table 5 shows equations of reactions $(1$ - 12) with the generation of Au-Ag sulfides, $\Delta \mathrm{rG}$ and Eh of the reactions at $25^{\circ} \mathrm{C}$ and $100^{\circ} \mathrm{C}(\mathrm{p}=1 \mathrm{bar})$.

Reactions for the dissolved sulfur components are also provided [24], hence they are not provided in the Table. Reactions with native gold are included in the Table for pure silver (Ag) and pure gold ( $\mathrm{Au}$ ) only. The calculation results served as the basis for the Ag-Au-S- $\mathrm{H}_{2} \mathrm{O}$ system. Eh-pH diagrams were built with various activities of dissolved sulfur $(0.1-0.001 \mathrm{~m})$ in water. Figure 10(a) provides an example of the stability fields of

Table 5. Chemical equations, $\Delta \mathrm{rG}_{298.1}$ and $\mathrm{Eh}$ for the $\mathrm{Ag}-\mathrm{Au}-\mathrm{S}-\mathrm{H}_{2} \mathrm{O}$ system at $25^{\circ} \mathrm{C}$ and $100^{\circ} \mathrm{C}, 1 \mathrm{bar}$.

\begin{tabular}{|c|c|c|c|}
\hline No. & Chemical Equations & $\begin{array}{l}\Delta \mathrm{rG}, \mathrm{J} / \mathrm{mol} \\
25^{\circ} \mathrm{C} / 100^{\circ} \mathrm{C}\end{array}$ & $\begin{aligned} \mathrm{Eh}_{298,1}= & -\mathrm{E} 0+0.05916 / \mathrm{n} * \lg \mathrm{K} \\
& 25^{\circ} \mathrm{C} / 100^{\circ} \mathrm{C}\end{aligned}$ \\
\hline 1 & $2 \mathrm{Ag}+\mathrm{H}_{2} \mathrm{~S}_{-\mathrm{aq}}=\mathrm{Ag}_{2} \mathrm{~S}+2 \mathrm{H}^{+}+2 \mathrm{e}$ & $-11673.4 /-6033$ & $\begin{array}{l}-0.0605-0.0285 *\left(2 \mathrm{pH}+\lg \mathrm{mH}_{2} \mathrm{~S}\right) / \\
0.03126-0.0285 *\left(2 \mathrm{pH}+\lg \mathrm{mH}_{2} \mathrm{~S}\right)\end{array}$ \\
\hline 2 & $2 \mathrm{Ag}+\mathrm{H}_{2} \mathrm{~S}_{-\mathrm{aq}}=\mathrm{Ag}_{2} \mathrm{~S}+\mathrm{H}^{+}+2 \mathrm{e}$ & $-51588.7 /-52366$ & $\begin{array}{l}-0.2673-0.0285 *\left(\mathrm{pH}+\lg \mathrm{mHS}^{-}\right) / \\
-0.27136-0.0285 *\left(\mathrm{pH}+\lg \mathrm{mHS}^{-}\right)\end{array}$ \\
\hline 3 & $\mathrm{Ag}_{2} \mathrm{~S}+4 \mathrm{H}_{2} \mathrm{O}=2 \mathrm{Ag}+\mathrm{HSO}_{4}^{-}+7 \mathrm{H}^{+}+6 \mathrm{e}$ & $232245.5 / 251600$ & $\begin{array}{l}0.4012+0.00986 *\left(-7 \mathrm{pH}+\lg \mathrm{mHSO}_{4}^{-}\right) / \\
0.4346+0.00986 *\left(-7 \mathrm{pH}+\lg \mathrm{mHSO}_{4}^{-}\right)\end{array}$ \\
\hline 4 & $\mathrm{Ag}_{2} \mathrm{~S}+4 \mathrm{H}_{2} \mathrm{O}=2 \mathrm{Ag}+\mathrm{SO}_{4}^{2-}+8 \mathrm{H}^{+}+6 \mathrm{e}$ & 243626.0/273032 & $\begin{array}{l}0.4208+0.00986 *\left(-8 \mathrm{pH}+\lg \mathrm{mSO}_{4}^{2-}\right) / \\
0.4716+0.00986 *\left(-8 \mathrm{pH}+\lg \mathrm{mSO}_{4}^{2-}\right)\end{array}$ \\
\hline 5 & $3 \mathrm{Ag}_{2} \mathrm{~S}+2 \mathrm{Au}+\mathrm{H}_{2} \mathrm{~S}_{\mathrm{aq}}=2 \mathrm{Ag}_{3} \mathrm{AuS}_{2}+2 \mathrm{H}^{+}$ & 8286.0/18011 & $\begin{array}{l}0.0429-0.0285 *\left(2 \mathrm{pH}+\lg \mathrm{mH}_{2} \mathrm{~S}\right) / \\
0.09333-0.0285 *\left(2 \mathrm{pH}+\lg \mathrm{mH}_{2} \mathrm{~S}\right)\end{array}$ \\
\hline 6 & $3 \mathrm{Ag}_{2} \mathrm{~S}+2 \mathrm{Au}+\mathrm{HS}^{-}=2 \mathrm{Ag}_{3} \mathrm{AuS}_{2}+\mathrm{H}^{+}+2 \mathrm{e}$ & $-31629.36 /-28322$ & $\begin{array}{l}-0.1639-0.0285 *\left(\mathrm{pH}+\lg \mathrm{mHS}^{-}\right) / \\
-0.1468-0.0285 *\left(\mathrm{pH}+\lg \mathrm{mHS}^{-}\right)\end{array}$ \\
\hline 7 & $2 \mathrm{Ag}_{3} \mathrm{AuS}_{2}+4 \mathrm{H}_{2} \mathrm{O}=2 \mathrm{Ag}_{2} \mathrm{~S}+2 \mathrm{Au}+\mathrm{HSO}_{4}^{-}+7 \mathrm{H}^{+}+6 \mathrm{e}$ & 212286.1/222201 & $\begin{array}{l}0.3666+0.00986 *\left(-7 \mathrm{pH}+\lg \mathrm{mHSO}_{4}^{-}\right) / \\
0.3838+0.00986 *\left(-7 \mathrm{pH}+\lg \mathrm{mHSO}_{4}^{-}\right)\end{array}$ \\
\hline 8 & $2 \mathrm{Ag}_{3} \mathrm{AuS}_{2}+4 \mathrm{H}_{2} \mathrm{O}=3 \mathrm{Ag}_{2} \mathrm{~S}+2 \mathrm{Au}+\mathrm{SO}_{4}^{2-}+8 \mathrm{H}^{+}+6 \mathrm{e}$ & $223666.6 / 243633$ & $\begin{array}{l}0.38635+0.00986 *\left(-8 \mathrm{pH}+\lg \mathrm{mSO}_{4}^{2-}\right) / \\
0.4208+0.00986 *\left(-8 \mathrm{pH}+\lg \mathrm{mSO}_{4}^{2-}\right)\end{array}$ \\
\hline 9 & $\mathrm{Ag}_{3} \mathrm{AuS}_{2}+2 \mathrm{Au}+\mathrm{H}_{2} \mathrm{~S}_{\mathrm{aq}}=3 \mathrm{AgAuS}+2 \mathrm{H}^{+}+2 \mathrm{e}$ & $14571.5 / 23366$ & $\begin{array}{l}0.0755-0.0285 *\left(2 \mathrm{pH}+\lg \mathrm{mH}_{2} \mathrm{~S}\right) / \\
0.12108-0.0285 *\left(2 \mathrm{pH}+\lg \mathrm{mH}_{2} \mathrm{~S}\right)\end{array}$ \\
\hline 10 & $\mathrm{Ag}_{3} \mathrm{AuS}_{2}+2 \mathrm{Au}+\mathrm{HS}^{-}=2 \mathrm{AgAuS}+\mathrm{H}^{+}+2 \mathrm{e}$ & $-25343.8 /-22967$ & $\begin{array}{l}-0.1313-0.0285 *\left(\mathrm{pH}+\lg \mathrm{mHS}^{-}\right) / \\
-0.1190-0.0285 *\left(\mathrm{pH}+\lg \mathrm{mHS}^{-}\right)\end{array}$ \\
\hline 11 & $3 \mathrm{AgAuS}+4 \mathrm{H}_{2} \mathrm{O}=\mathrm{Ag}_{3} \mathrm{AuS}_{2}+2 \mathrm{Au}+\mathrm{HSO}_{4-}+7 \mathrm{H}^{+}+6 \mathrm{e}$ & 206000.6/222201 & $\begin{array}{l}0.3558+0.00986 *\left(-7 \mathrm{pH}+\lg \mathrm{mHSO}_{4}^{-}\right) / \\
0.3838+0.00986 *\left(-7 \mathrm{pH}+\lg \mathrm{mHSO}_{4}^{-}\right)\end{array}$ \\
\hline 12 & $2 \mathrm{Ag}_{3} \mathrm{AuS}_{2}+4 \mathrm{H}_{2} \mathrm{O}=3 \mathrm{Ag}_{2} \mathrm{~S}+2 \mathrm{Au}+\mathrm{SO}_{4}^{2-}+8 \mathrm{H}^{+}+6 \mathrm{e}$ & 217381.1/243633 & $\begin{array}{l}0.3755+0.00986 *\left(-8 \mathrm{pH}+\lg \mathrm{mSO}_{4}^{2-}\right) / \\
0.4208+0.00986 *\left(-8 \mathrm{pH}+\lg \mathrm{mSO}_{4}^{2-}\right)\end{array}$ \\
\hline
\end{tabular}

$\mathrm{Eh}=\mathrm{Eh}_{0}+\frac{\mathrm{RT}}{\mathrm{n} * \mathrm{~F}} * \ln \left(\frac{\mathrm{a}_{\text {oxid }}}{\mathrm{a}^{\mathrm{addix}}}\right), \mathrm{Eh}_{0}=-\frac{\Delta \mathrm{rG}}{\mathrm{n} * \mathrm{~F}}, \mathrm{~A}=2.3026 \mathrm{RT} /(\mathrm{nF})$, where $\mathrm{R}$ is the universal gas constant $1.98717 \times 4.184 \mathrm{~J} /(\mathrm{deg}), \mathrm{T}$ is temperature, $\mathrm{K}$; $\mathrm{n}$ is the number of electrons; and $\mathrm{F}$ is the Faraday constant $(96487 \mathrm{~J} /($ Volt.g-equiv. $=\mathrm{mol})$. 
acanthite, uytenbogaardtite, petrovskaite, also sulfur, silver and gold at $25^{\circ} \mathrm{C}$ for the total activity of dissolved sulfur $0.001 \mathrm{~m}$, which corresponds to an average $\mathrm{SO}_{4}$ content in the Dorozhnoye deposit water streams.

We can see that the petrovskaite field is located in a strongly acidic medium under redox conditions near the sulfide-sulfate equilibrium line. The uytenbogaardtite field is wider than petrovskaite and is situated in the zone of weakly acidic and almost neutral solutions. The acanthite stability field has a wider range of $\mathrm{pH}$ including weakly alkaline solutions. These minerals can be formed both under reduction conditions with the participation of sulfide components ( $\mathrm{H}_{2} \mathrm{~S}$ and $\left.\mathrm{HS}-\right)$ and in an oxidizing environment with dominating sulfates $\left(\mathrm{HSO}_{4}^{-}\right.$and $\mathrm{SO}_{4}^{2-}$ ) in solution. With an increasing temperature, at $100^{\circ} \mathrm{C}$ (Figure $10(\mathrm{~b})$ ) with the same total sulfur activity
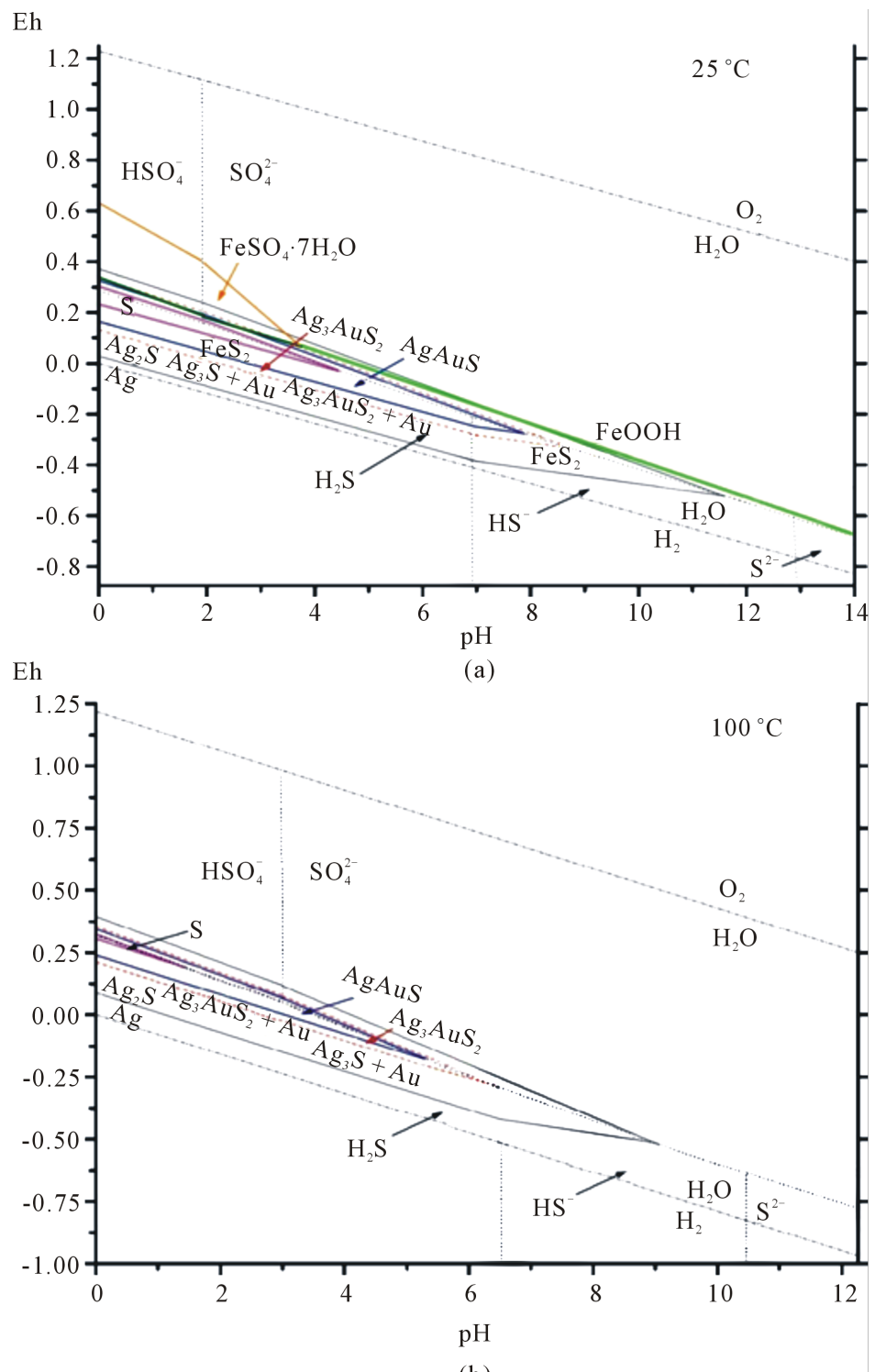

(b)

Figure 10. Eh-pH diagram showing the stability fields of solid phases-acanthite $\left(\mathrm{Ag}_{2} \mathrm{~S}\right)$, uytenbogaardtite $\left(\mathrm{Ag}_{3} \mathrm{AuS}_{2}\right)$, petrovskaite (AgAuS), native sulfur $(\mathrm{S})$, gold $(\mathrm{Au})$ and silver $(\mathrm{Ag})$ in the system $\mathrm{Ag}-\mathrm{Au}-\mathrm{S}-\mathrm{H}_{2} \mathrm{O}$ at $25^{\circ} \mathrm{C}$ (a) and $100^{\circ} \mathrm{C} \mathrm{(b)} \mathrm{(p} \mathrm{=} 1$ bar) and total activity of sulfur $\Sigma \mathrm{S}=$ 0.001 . Dash-dotted lines are the upper and lower stability limits of water; thin dotted lines share the predominance of dissolved forms of sulfur in water at a given T, P-parameters. Figure additionally shows the stability fields of melanterite $\left(\mathrm{FeSO}_{4} \cdot 7 \mathrm{H}_{2} \mathrm{O}\right)$, goethite $(\mathrm{FeOOH})$, and pyrite $\left(\mathrm{FeS}_{2}\right)$. 
(0.001 m), the stability field of all Au-Ag sulfides decreases considerably in size. At the same time, an increase in total activities of up to $0.1 \mathrm{~m}$ has the effect of widening the range of $\mathrm{pH}$ and oxidizing environment at $25^{\circ} \mathrm{C}$ and $100^{\circ} \mathrm{C}$. It is worthy of note that the native sulfur field lies within the acanthite, uytenbogaardtite and petrovskaite stability fields. As was shown [25], Au-Agsulfides can be formed when crystalline or liquid sulfur react with previously sedimented native gold. The reactions are the following:

$$
\begin{gathered}
\mathrm{Au}_{\mathrm{x}} \mathrm{Ag}_{(1-\mathrm{x})}+0.5 *(1-\mathrm{x}) * \mathrm{~S}_{(\mathrm{s}, 1)}=0.5 *(1-\mathrm{x}) * \mathrm{Ag}_{2} \mathrm{~S}+\mathrm{x} * \mathrm{Au}, \\
\mathrm{Au}_{\mathrm{x}} \mathrm{Ag}_{(1-\mathrm{x})}+0.66 *(1-\mathrm{x}) * \mathrm{~S}_{(\mathrm{s}, 1)}=0.33 *(1-\mathrm{x}) * \mathrm{Ag}_{3} \mathrm{AuS}_{2}+0.33 *(4 \mathrm{x}-1) * \mathrm{Au} \\
\mathrm{Au}_{\mathrm{x}} \mathrm{Ag}_{(1-\mathrm{x})}+(1-\mathrm{x}) * \mathrm{~S}_{(\mathrm{s}, 1)}=(1-\mathrm{x}) * \mathrm{AgAuS}+(2 \mathrm{x}-1) * \mathrm{Au}
\end{gathered}
$$

The sulfur phase transition temperature is $113^{\circ} \mathrm{C}$. Such a temperature is rare in weathering crusts, so, it is logic that crystalline sulfur was the agent. Au-Ag sulfide composition, both in reactions 13 - 15 and with dissolved sulfur (sulfides and sulfates) (Table 6, Reactions 5 - 12), will depend on the amount of silver in native gold. If the gold fineness $\left(\mathrm{N}_{\mathrm{Au}}\right)$ is over $370 \%$, uytenbogaardtite can be formed, at $\mathrm{N}_{\mathrm{Au}}>650 \%$ - petrovskaite [26]. Figure 10(a), Figure 10(b) show that the native gold stability boundaries with different fineness will be located between the lines: $\mathrm{Ag} / \mathrm{Ag}_{2} \mathrm{~S}$ and $\left(\mathrm{Ag}_{2} \mathrm{~S}+\mathrm{Au}\right) / \mathrm{Ag}_{3} \mathrm{AuS}_{2}$ or $\left(\mathrm{Ag}_{2} \mathrm{~S}+\mathrm{Au}\right) / \mathrm{Ag}_{3} \mathrm{AuS}_{2}$ and $\left(\mathrm{Ag}_{3} \mathrm{AuS}_{2}+\mathrm{Au}\right) / \mathrm{AgAuS}$.

The thermodynamical calculations show that uytenbogaardtite and petrovskaite are formed both in the environment of excessive acidity near the sulfide-sulfate equilibrium line, i.e. in the reduction environment with $\mathrm{H}_{2} \mathrm{Saq}$, and in the oxidizing environment with dominating sulfates $\left(\mathrm{HSO}_{4}^{-}\right.$and $\mathrm{SO}_{4}^{2-}$ ) or crystalline sulfur. Dark rims on the native gold show an excessive acidity of solutions and redox environment near the sulfide-sulfate equilibrium lines.

In the oxidizing zone of the Dorozhnoye deposit uytenbogaardtite and petrovskaite were detected together with goethite and melanterite, but their reaction equations were calculated for the case when oxidizing pyrite generates these very minerals. Many Eh-pH diagrams and $\log \mathrm{f}_{\mathrm{O} 2}-\mathrm{pH}$ are known for the Fe-S- $\mathrm{H}_{2} \mathrm{O}$ systems. Diagrams by Garrels and Christ [24] show the fields of hematite, magnetite, pyrite and pyrrhotite. This system was considered in detail in one of the recent theses [27] describing the relations between oxides, hydroxides, sulfides, carbonates, sulfates and a number of iron aqueous sulfates. The Eh of the corresponding reactions (16 - 20) was calculated in order to determine stability fields of melanterite, quite a rare mineral (Table 6).

Thermodynamical constants for melanterite $\left(\mathrm{FeSO}_{4} \cdot 7 \mathrm{H}_{2} \mathrm{O}\right)$ were taken [28], those for goethite and pyrite from [23]. Figure 10(a) shows stability fields of these minerals. The melanterite field is located in the oxidizing environment in strongly acidic solutions with dominating sulfates (thin lines in Figure 10(a)). The goethite field is also located in the area with dominating sulfates $\left(\mathrm{SO}_{4}^{2-}\right)$; however, the environment is less acidic. Pyrite is stable mainly in a reducing environment with prevailing sulfides. Stability fields of iron minerals can be found in diagrams in [27]; however, they are not discussed in this paper.

Since the melanterite field is found in sulfate solutions only, uytenbogaardtite and petrovskaite are generated at the Dorozhnoye deposit in an oxidizing and acidic environment with sulfates prevailing over sulfides. Dark rims on the native gold and the presence of melanterite reveal an oxidized environment, and a solution of exces-

\begin{tabular}{|c|c|c|c|}
\hline No. & Chemical Equations & $\begin{array}{l}\Delta \mathrm{rG}, \mathrm{J} / \mathrm{mol} \\
25^{\circ} \mathrm{C} / 100^{\circ} \mathrm{C}\end{array}$ & $\begin{aligned} \mathrm{Eh}_{298,1}= & -\mathrm{E} 0+0.05916 / \mathrm{n} * \lg \mathrm{K} \\
& 25^{\circ} \mathrm{C} / 100^{\circ} \mathrm{C}\end{aligned}$ \\
\hline 16 & $\mathrm{FeS}_{2}+15 \mathrm{H}_{2} \mathrm{O}=\mathrm{FeSO}_{4} * 7 \mathrm{H}_{2} \mathrm{O}+\mathrm{HSO}_{4}^{-}+15 \mathrm{H}^{+}+14 \mathrm{e}$ & 457020.8 & $0.3383-0.0042 *\left(-15 \mathrm{pH}+\lg \mathrm{mHSO}_{4}^{-}\right)$ \\
\hline 17 & $\mathrm{FeS}_{2}+15 \mathrm{H}_{2} \mathrm{O}=\mathrm{FeSO}_{4} * 7 \mathrm{H}_{2} \mathrm{O}+\mathrm{SO}_{4}^{2-}+16 \mathrm{H}^{+}+14 \mathrm{e}$ & 468401.2 & $0.3468-0.0042 *\left(-16 \mathrm{pH}+\lg \mathrm{mSO}_{4}^{2-}\right)$ \\
\hline 18 & $\mathrm{FeS}_{2}+10 \mathrm{H}_{2} \mathrm{O}=\mathrm{FeOOH}+2 \mathrm{SO}_{4}^{2-}+19 \mathrm{H}^{+}+15 \mathrm{e}$ & 89271.48 & $0.9252+0.003944 *\left(-19 \mathrm{pH}+\lg \mathrm{mSO}_{4}^{2-}\right)$ \\
\hline 19 & $\mathrm{FeSO}_{4} * 7 \mathrm{H}_{2} \mathrm{O}=\mathrm{FeOOH}+\mathrm{HSO}_{4}^{-}+5 \mathrm{H}_{2} \mathrm{O}+2 \mathrm{H}^{+}+\mathrm{e}$ & 77891.0 & $0.8073+0.05916 *\left(-2 \mathrm{pH}+\lg \mathrm{mHSO}_{4}^{-}\right)$ \\
\hline 20 & $\mathrm{FeSO}_{4} * 7 \mathrm{H}_{2} \mathrm{O}=\mathrm{FeOOH}+\mathrm{SO}_{4}^{2-}+5 \mathrm{H}_{2} \mathrm{O}+3 \mathrm{H}^{+}+\mathrm{e}$ & 89271.5 & $0.9252+0.05916 *\left(-3 \mathrm{pH}+\lg \mathrm{mSO}_{4}^{2-}\right)$ \\
\hline
\end{tabular}
sive acidity with high concentrations of sulfates.

Table 6. Equations, $\Delta \mathrm{rG}$ and $\mathrm{Eh}$ of pyrite oxidation reactions with melanterite and goethite. $\mathrm{T}=25^{\circ} \mathrm{C}, \mathrm{p}=1 \mathrm{bar}$. 


\section{Discussion}

The Dorozhnoye gold ore deposit differs from the deposits of the Yano-Kolymskyorogenic belt by means of its unusual geology and structure, specific alterations, native gold fineness (530\% - 700\%o), and the presence of freibergite, stephanite, pyrargyrite and Bi-diaphorite, across a wide-spread area of Au-Ag sulfides in the oxidizing area (petrovskaite and uytenbogaardtite), as well as by the presence of Fe-goethite and melanterite. The Dorozhnoye deposit has the following structural peculiarity: by the time when gold mineralization was formed, concentric cracks, as opposed to radial cracks (occurring in most mesothermal gold ore deposits located in stocks of intrusive rocks) became half-opened (contraction cracks in the process of cooling), while radial fissures served as feeding channels. This helped to generate ore bodies with flat $5^{\circ}-10^{\circ}$ dipping angles, when during the process of ore sedimentation, silver, being geochemically more mobile, as opposed to gold, was not conveyed to the upper levels (as occurs with steep veins) but met the cracks and remained in the ore-hosting cavity. As a result, the following minerals were formed in ores: electrum $\mathrm{Au}_{0.50} \mathrm{Ag}_{0.50}$ (at an average fineness of 650\%), silver-containing galena and sphalerite with a lamellae of pyrargyrite, stephanite, freibergite and diaphorite.

Thermometrical studies of fluid inclusions within quartz at the Dorozhnoye deposit reveal that the oreformation was at a temperature ranging from $340^{\circ} \mathrm{C}$ to $118^{\circ} \mathrm{C}$. At the same time, the solution concentrations decreased from $11.7 \mathrm{wt} \%$ to $0.18 \mathrm{wt} \%$ eq. $\mathrm{NaCl}$, and the fluid composition changed considerably from predominantly $\mathrm{K}$-chloride and $\mathrm{K}$-carbonate to $\mathrm{Na}$-(Mg)-chloride. The typomorphic characteristics of native gold and fluid inclusions within gold ore vein quartz, as well as the metasomatic alterations (sericitization and bericitization), show that the sedimentation of gold and silver minerals occured at relatively low temperatures from weakly acidic chloride solutions-from $165^{\circ} \mathrm{C}$ to $125^{\circ} \mathrm{C}$. The results comply with the data in theses [29]-[31] which prove that low gold-silver ratios in ore $(\mathrm{Au}: \mathrm{Ag}) \approx 1: 1-1: 20$ and low fineness gold are caused by $100^{\circ} \mathrm{C}-400^{\circ} \mathrm{C}$ hot weakly acidic, almost neutral, moderately chloride solutions with dominating transportation forms as AuHS ${ }^{0}$ for gold and $\mathrm{AgCl}_{2}^{-}$for silver.

Hypergene minerals_-high fineness gold, petrovskaite, goethite and melanterite — appear to have been formed in an oxidized environment and exceedingly acidic solutions at a concentration of sulfates of $10^{-4}-10^{-1} \mathrm{~mol} / 1$ $\mathrm{kg} \mathrm{H}_{2} \mathrm{O}$ as a result of the following reactions of surface waters and electrum and pyrite, minerals of the earliest hydrothermal stages:

$$
\begin{aligned}
& \mathrm{Au}_{\mathrm{x}} \mathrm{Ag}_{1-\mathrm{x}}+\mathrm{FeS}_{2}+(1.5+\mathrm{x}) \mathrm{H}_{2} \mathrm{O}+(2.25+1.5 \mathrm{x}) \mathrm{O}_{2} \\
& \rightarrow \mathrm{FeOOH}+(1+\mathrm{x}) \mathrm{HSO}_{4^{-}}+(1+\mathrm{x}) \mathrm{H}^{+}+(1-\mathrm{x}) \mathrm{AgAuS}+(2 \mathrm{x}-1) \mathrm{Au},
\end{aligned}
$$

or

$$
\begin{aligned}
& \mathrm{Au}_{\mathrm{x}} \mathrm{Ag}_{1-\mathrm{x}}+\mathrm{FeS}_{2}+(8+\mathrm{x}) \mathrm{H}_{2} \mathrm{O}+(3.5+1.5 \mathrm{x}) \mathrm{O}_{2} \\
& \rightarrow \mathrm{FeSO}_{4} * 7 \mathrm{H}_{2} \mathrm{O}+(1+\mathrm{x}) \mathrm{HSO}_{4^{-}}+(1+\mathrm{x}) \mathrm{H}^{+}+(1+\mathrm{x}) \mathrm{H}^{+}+(1-\mathrm{x}) \mathrm{AgAuS}+(2 \mathrm{x}-1) \mathrm{Au},
\end{aligned}
$$

These minerals could also have been formed at the Dorozhnoye deposit with the participation of silver minerals, lead and zinc sulfides.

\section{Conclusions}

The mineralization process at the Dorozhnoye deposit is comprised of four stages. Quartz-molybdenite and quartz-cassiterite paragenesis were formed during the first stage. The second quartz-arsenopyrite stage forms galena, freibergite, stephanite, pyrargyrite, Bi-diaphorite and electrum. The third quartz-carbonate stage is unproductive. The fourth hypergene stage forms high fineness gold, Au-Ag sulfides (petrovskaite, uytenbogaardtite), together with hydroxides, aqueous sulfates and iron arsenates.

Temperatures of the formation of quartz-molybdenite and quartz-cassiterite veins are close with range from $360^{\circ} \mathrm{C}-170^{\circ} \mathrm{C}$. Those temperatures differ considerably from the later gold-sulfide-quartz paragenesis $\left(165^{\circ} \mathrm{C}-\right.$ $125^{\circ} \mathrm{C}$ ). It was stated that the composition of the fluid was subject to change during ore sedimentation from Na-Mg-chloride to Na-K-chloride-carbonate.

Thermodynamical calculations show that uytenbogaardtite and petrovskaite form in redox environment near the zone of sulfide-sulfate equilibrium, under conditions of excessive acidity and with the participation of sulfides $\left(\mathrm{H}_{2} \mathrm{~S}_{\mathrm{aq}}\right)$ or sulfates $\left(\mathrm{HSO}_{4}^{-}\right.$and $\left.\mathrm{SO}_{4}^{2-}\right)$. Au-Ag sulfides at the Dorozhnoye deposit are formed under oxi- 
dizing conditions and an acidic environment with dominating sulfates.

\section{Acknowledgements}

We thank Sanko E.S. for quartz thermography. We thank the Russian Foundation for Basic Research, FEB RAS and SB RAS for funding this research (grants No. 14-05-00504a, FEB RAS 12-II-0-08-28 Project and No. 48 Integration Project of SB RAS and FEB RAS).

\section{References}

[1] Firsov, L.V. (1959) The Dorozhnoye Gold Ore Deposit. Works by VNII-1 54, 1-19.

[2] Kalinin, A.I. (1993) Report of Prospecting Works at the Dorozhnoye Ore Manifestation for 1990-1992. Sevvostgeolkom, Magadan.

[3] Al'shevskii, A.V. (2001) Gold Sulfide Minerals in Northeastern Russia: Occurrence, Composition, and Genesis. The Problems of Geology and Metallogeny in Northeastern Russia at the Boundary of the Millennia. 2, 135-138.

[4] Sharafutdinov, V.M. and Khasanov, I.M. (2010) Study of Electric Characteristics of Several Gold Ore Deposits of the Russian North-East. Modern Problems of Science and Education. 2, 28-35.

[5] La Bas, M.J., Maitr, R.V., Streckeisen, A. and Zannettin, B.A. (1986) A Chemical Classification of Volcanic Rocks Based on the Total Alkali-Silica Diagram. Journal of Petrology, 27, 745-750. http://dx.doi.org/10.1093/petrology/27.3.745

[6] Piskunov, L.L. (1987) Geologo-Petrologic Particularity of Volcanism of Island Arcs. Nauka, Moscow.

[7] Whiteford, D.G., Nicholls, I.A. and Taylor, S.R. (1979) Spatial Variations in the Geochemistry of Quaterraty Lavas across the Sundaarc in Java and Bali. Contributions to Mineralogy and Petrology, 70, 341-356. http://dx.doi.org/10.1007/BF00375361

[8] Pal'yanova, G.A. and Savva, N.E. (2008) Some Sulfides of Gold and Silver: Composition, Mineral Assemblage, and Conditions of Formation. Theoretical Foundations of Chemical Engineering, 42, 749-761. http://dx.doi.org/10.1134/S0040579508050485

[9] Savva, N.E. and Palyanova, G.A. (2007) Genesis of Gold and Silver Sulphides at the Ulakhan Deposit (Northeastern Russia). Russian Geology and Geophysics, 48, 799-810. http://dx.doi.org/10.1016/j.rgg.2007.09.006

[10] Savva, N.E., Palyanova, G.A. and Kolova, E.E. (2010) Gold and Silver Minerals in Zone of Secondary Sulfide Enrichment (Krutoe Ore Occurrence, Northeastern Russia). Vestnik SVNTs DVO RAN 1, 33-45.

[11] Urgenson, G.A. (1984) Typomorphism and Mineralization of Vein Quartz. Nedra, Moscow.

[12] Goryachev, N.A. (1992) Gold-Quartz Vein Deposits of the Yano-Kolymsky Belt. FEB RAS, Vladivostok.

[13] Borisenko, A.S. (1977) Studies of Salinity of Gas-Liquid Inclusions in Minerals by the Cryometric Method. Soviet GeolGeophys, 18, 11-19.

[14] Bodnar, R.J. and Vityk, M.O. (1994) Interpretation of Microthermometric Data for $\mathrm{H}_{2} \mathrm{O}-\mathrm{NaCl}$ Fluid Inclusions. In: De Vivo, B. and Frezzotti, M.L., Eds., Fluid Inclusions in Minerals: Methods and Application, Pontignsno-Siena, 117130.

[15] Ermakov, N.P. and Dolgov, Y.A. (1979) Thermobarogeochemistry. Nedra, Moscow.

[16] Melnikov, F.P., Prokofyev, V.Y. and Shatagin, N.N. (2008) Thermobarogeochemistry: Textbook for Higher Schools. Academichesky Project, Moscow.

[17] Ryodder, E. (1987) Fluid Inclusions in Minerals. Mir, Moscow.

[18] Krupp, R.E. and Weiser, T. (1992) On the Stability of Gold-Silver Alloys in the Weathering Environment. Mineralium Deposita, 27, 268-275. http://dx.doi.org/10.1007/BF00193397

[19] Webster, J.G. (1986) The Solubility of Gold and Silver in the System Au-Ag-S- $\mathrm{O}_{2}-\mathrm{H}_{2} \mathrm{O}$ at $25^{\circ} \mathrm{C}$ and $1 \mathrm{~atm}$. Geochimica et Cosmochimica Acta, 50, 1837-1845. http://dx.doi.org/10.1016/0016-7037(86)90242-5

[20] Firsov, L.V. (1985) Gold-Quartz Formation of the Yano-Kolymsky Belt. Nauka, Novosibirsk.

[21] O’Donoghue, M. (1987) Quartz. Butterworth \& Co (Publishers) Ltd., London.

[22] Osadchii, E.G. and Rappo, O.A. (2004) Determination of Standard Thermodynamic Properties of Sulfides in the AgAu-S System by Means of a Solid-State Galvanic Cell. American Mineralogist, 89, 1405-1410.

[23] Robie, R.A. and Hemingway, B.S. (1995) Thermodynamic Properties of Minerals and Related Substances at 298.15 and 1 Bar $\left(10^{5}\right.$ Pascals) Pressure and at Higher Temperatures. US Geological Survey Bulletin 2131.

[24] Garrels, R.M. and Christ, C.L. (1968) Solutions, Minerals, and Equilibria. Mir, Moscow. 
[25] Savva, N.E., Palyanova, G.A. and Byankin, M.A. (2012) The Problem of Genesis of Gold and Silver Sulfides and Selenides in the Kupol Deposit (Chukotka, Russia). Russian Geology and Geophysics, 53, 457-466. http://dx.doi.org/10.1016/j.rgg.2012.03.006

[26] Palyanova, G., Karmanov, N. and Savva, N. (2014) Sulfidation of Native Gold. American Mineralogist, 99, 1095-1103. http://dx.doi.org/10.2138/am.2014.4677

[27] Rickard, D. and Luther, G. (2007) Chemistry of Iron Sulfides. Chemical Reviews, 107, 514-562. http://dx.doi.org/10.1021/cr0503658

[28] Krivovichev, V.G., Charykov, M.V., Yakovenko, O.S. and Depmayer, V. (2010) Thermodynamics of Arsenates, Selenites and Sulfates in the Sulfide Ore Oxidizing Zone. II. The Systems $\mathrm{M}_{1}, \mathrm{M}_{2} / / \mathrm{SO}_{4}{ }^{2-}-\mathrm{H}_{2} \mathrm{O}\left(\mathrm{M}_{1}, \mathrm{M}_{2}=\mathrm{Fe}^{2+}, \mathrm{Fe}^{3+}, \mathrm{Cu}^{2+}\right.$, $\mathrm{Zn}^{2+}, \mathrm{Pb}^{2+}, \mathrm{Ni}^{2+}, \mathrm{Co}^{2+}, \mathrm{H}^{+}$) at $25^{\circ} \mathrm{C}$. Zapiski $\mathrm{RMO}, 139,3-18$.

[29] Palyanova, G. (2008) Physicochemical Modeling of the Coupled Behavior of Gold and Silver in Hydrothermal Processes: Gold Fineness, Au/Ag Ratios and Their Possible Implications. Chemical Geology, 255, 399-413. http://dx.doi.org/10.1016/j.chemgeo.2008.07.010

[30] Palyanova, G.A. (2008) Physicochemicalbehavior of Gold and Silver during the Process of Hydrothermal Ore Formation. SB RAS, Novosibirsk.

[31] Palyanova, G.A. and Kolonin, G.R. (2007) Geochemical Mobility of Au and Ag during Hydrothermal Transfer and Precipitation: Thermodynamic Simulation. Geochemistry International, 45, 744-757. http://dx.doi.org/10.1134/S0016702907080022 